Research Article

\title{
Efficient Crisis Management by Selection and Analysis of Relief Centers in Disaster Integrating GIS and Multicriteria Decision Methods: A Case Study of Tehran
}

\author{
Hassan Ahmadi Choukolaei, ${ }^{1}$ Mustafa Jahangoshai Rezaee ${ }^{(D)},{ }^{1}$ Peiman Ghasemi, \\ and Morteza Saberi ${ }^{3}$ \\ ${ }^{1}$ Faculty of Industrial Engineering, Urmia University of Technology, Urmia, Iran \\ ${ }^{2}$ Department of Industrial Engineering, South Tehran Branch, Islamic Azad University, Tehran, Iran \\ ${ }^{3}$ School of Information, Systems and Modelling, University of Technology Sydney, Sydney, NSW, Australia \\ Correspondence should be addressed to Mustafa Jahangoshai Rezaee; m.jahangoshai@uut.ac.ir
}

Received 28 April 2021; Revised 21 May 2021; Accepted 17 June 2021; Published 2 July 2021

Academic Editor: Mohammad Yazdi

Copyright (c) 2021 Hassan Ahmadi Choukolaei et al. This is an open access article distributed under the Creative Commons Attribution License, which permits unrestricted use, distribution, and reproduction in any medium, provided the original work is properly cited.

\begin{abstract}
In Iran, location is usually done by temporary relief organizations without considering the necessary standards or conditions. The inappropriate and unscientific location may have led to another catastrophe, even far greater than the initial tragedy. In this study, the proposed locations of crisis management in the region and the optimal points proposed by the Geographic Information System (GIS), taking into account the opinions of experts and without the opinion of experts, were evaluated according to 18 criteria. First, the optimal areas have been evaluated according to standard criteria extracted by GIS and the intended locations of the region for accommodation in times of crisis. Then, the position of each place is calculated concerning each criterion. The resulting matrix of optimal options was qualitatively entered into the Preference Ranking Organization Method for Evaluation (PROMETHEE) for analysis. The triangular fuzzy aggregation method for weighting and standard classification of criteria for extracting optimal areas using GIS and integrating entropy and the Multiobjective Optimization Based on Ratio Analysis (MOORA) method for prioritizing places in the region are considered in this research. Finally, by applying constraints and using net input and output flows, optimal and efficient options are identified by PROMETHEE V. Among the research options, only four options were optimal and efficient. A case study of the Tehran metropolis is provided to show the ability of the proposed approach for selecting the points in three modes, with/without applying weights and applying crisis management.
\end{abstract}

\section{Introduction}

Natural disasters, especially earthquakes, have long been considered the most destructive factors that harm humans, society, and habitat. Data show that natural disasters such as earthquakes have increased in recent years. Therefore, the need for proper planning for equipment before the disaster is more important than ever [1-3]. During a crisis, homes are often damaged or unsafe for use, and at this time, creating suitable temporary shelters for families is very important. Temporary shelter is transferring people from emergency shelters to their permanent housing, which is provided to homeless families for several months to several years. Transforming urban spaces into temporary shelters is an effective way to support and improve the aftermath of natural disasters [4]. The process of selecting a temporary location for use in future critical situations must be done in a principled manner. Because the main need of the injured people is to have shelter and provide relief services in the fastest possible time, it is not possible to provide suitable places for earthquake victims immediately after the earthquake. In such crises, the right places (urban access, security, avoidance of risk-prone areas, and so on) should be provided to earthquake victims [5]. Because the injured person 
without shelter is exposed to serious physical, mental, and psychological injuries. For this reason, selecting an appropriate and safe location is very important in urban planning. Improper location of relief centers will lead to a crisis far worse than the initial crisis. For example, not observing the distance between relief centers and fault lines will lead to the destruction of these places during aftershocks, which will injure or kill many people due to the role of relief centers in crises. Due to the active faults in the region and the importance of locating relief centers in times of crisis, in this study, relief centers considered by Tehran Crisis Management with optimal centers extracted by the Geographic Information System (GIS) in terms of efficiency, performance, and optimization have been evaluated. Also, in this study, by comparing the desired methods and locations in the area and the proposed locations of GIS, it has been tried to introduce the most optimal locations or areas for temporary accommodation of people in critical situations by evaluating potential locations and areas. Comparison and review of points considered by the Regional Crisis Management Organization and points introduced by GIS are other topics studied in this research. Many researchers have focused specifically on planning and policy-making. Researchers and crisis management managers are willing to act in decisions that can improve system performance as much as possible. Hosseini and Machyani [6] identified and ranked places prone to food storage and facilities in times of crisis. They used the GIS method and the AHP method. Esmaelian et al. [7] proposed a multicriteria spatial decision that integrates a GIS support system and a multicriteria decision method to identify evacuation shelters and emergency service locations. Marcelin et al. [8] have adopted a p-median modeling framework with GIS. Their goal was to discover the locations of relief distribution facilities after a possible storm in the city of Leon, Florida. Chen et al. [9] designed a system theory-based planning framework and GIS in China for urban emergency shelters in critical situations. In this study, the opinions of local experts and citizens were used to build temporary settlements in Guangzhou. The results showed that this framework is a good tool for planning urban emergency shelters. Saeidian et al. [10] have used (GIS), TOPSIS method, a simple clustering method, and two metaheuristic algorithms (particle swarm optimization (PSO) and ant colony optimization (ACO)) to locate relief centers. The results of the evaluations showed that PSO responds better than ACO and has higher adaptability. Nappi et al. [11] have proposed a new multicriteria decision model that focuses on humanitarian to select temporary collective shelters. The results quantify the importance of criteria and allow the development of a SHELTERPRO software decision tool that can be used for support. The results also showed that facility safety, cultural adequacy, and access to space were the most valuable criteria. Baharmand et al. [12] have developed a spatial allocation model and applied their approach to a real data set of Nepal 2015 earthquake response. The analysis showed that with a relative coverage of 0.4 , the balance between procurement costs and response time affects the number and location. Borhani et al. [13] identified the shelters and multipurpose spaces by analyzing the collected data and the opinions of 26 experts using the GIS and SAW model. Su et al. [14] developed a two-stage floating catchment (2SFCA) method with variable service radius, and evacuation radius has been developed to describe emergency shelter access in the main Lanzhou area and compare it with traditional 2SFCA. Yao et al. [15] used a multicriteria TOPSIS evaluation model and, through a combined process, service area, and POI analysis, developed a model that provided an overall assessment at the district level. The results showed that the distribution of open spaces did not match the dynamics of population distribution. Considering the existing challenges in the literature of the subject as well as the analysis of studies, the research gap can be expressed as follows:

(i) Lack of attention to location constraints

(ii) Lack of attention to the efficiency of the optimal locations

(iii) Lack of attention to the feasibility of the output of the GIS

Given the research gap mentioned, the research contributions are listed as follows:

(i) Using PROMETHEE V to consider constraints to suggest optimal locations

(ii) Determining the efficiency of the final optimal options according to the net input and output currents

(iii) Determining the feasibility of the extracted places

The rest of the paper is organized as follows. In the second section, the criteria for measuring criteria and ranking options will be explained. In Section 3, the proposed approach and problem statement will be expressed. In Section 4, we will introduce a case study. In the fifth and sixth sections, the data, output analysis, and related results will be described, respectively. Finally, the conclusion will be stated in the last section.

\section{Methodology}

The methodology of this research consists of four parts. These methods were used to weigh the criteria and prioritize the options. Research weighting methods include the triangular fuzzy method and entropy. MOORA and PROMETHEE methods have also been used to prioritize options. The entropy-MOORA combination method was used in the second phase of the research to rank the relief sites in the area, and the PROMETHEE method was used to prioritize the options. The PROMETHEE V method has been used to determine the final optimal options and compare the performance of the methods.

2.1. Weighting Method. The use of fuzzy sets is more compatible with linguistic and sometimes ambiguous human explanations. Therefore, it is better to use long-term predictions and real-world decisions using fuzzy numbers. Each triangular fuzzy number consists of three parameters 
$F=(l \cdot m \cdot u)$. The upper bound $(u)$ is the maximum value that a fuzzy number $\mathrm{F}$ can take. The lower bound $(l)$ is the minimum value that a fuzzy number can take, and $m$ is the most probable value of a fuzzy number.

$$
\mu_{F}(x)= \begin{cases}\frac{x-l}{m-l}, & l<x<m, \\ \frac{u-x}{u-m}, & m<x<u, \\ 0, & \text { otherwise. }\end{cases}
$$

In this weighting step, the sum of triangular fuzzy numbers is obtained according to the following formula:

$$
\begin{aligned}
F_{1} & =\left(l_{1} \cdot m_{1} \cdot u_{1}\right), \\
F_{1}+F_{2} & =\left(l_{1}+l_{2} \cdot m_{1}+m_{2} \cdot u_{1}+u_{2}\right), \\
F_{2} & =\left(l_{2} \cdot m_{2} \cdot u_{2}\right) .
\end{aligned}
$$

After collecting the criteria and evaluating them, the experts evaluated the criteria fuzzy $(\mathrm{VH}, \mathrm{H}, \mathrm{M}, \mathrm{L}, \mathrm{VL})$. Then, the obtained fuzzy numbers were defuzzified, and the weights of the indicators were calculated and normalized.

2.2. Entropy Method. In this research, the entropy method has been used to determine the weight of the criteria. Entropy is used for calculating the weight of criteria. This method requires a criterion-option matrix. This method was proposed in 1974 by Shannon and Weaver [16]. Entropy represents the amount of uncertainty in a continuous probability distribution. The basic idea of this method is that the higher the scatter in the values of a criterion, the more important that criterion. First, the values of each cell of the matrix by the sum of the column values (simple normalization) are divided.

$$
n_{i j}=\frac{x_{i j}}{\sum_{i=1}^{m} x_{i j}} .
$$

The entropy value of characteristic $j$ is calculated as follows:

$$
E_{j}=-K \sum_{i=1}^{m} n_{i j} \ln \left(n_{i j}\right), \quad k=\frac{1}{\ln m},
$$

where $M$ is the number of options.

Using $\left(E_{j}\right)$, the values of $d_{j}$ for each characteristic are calculated:

$$
d_{j}=1-E_{j}
$$

By normalizing the values of $d_{j}$, the characteristic weight is obtained:

$$
W_{j}=\frac{d_{j}}{\sum_{j=1}^{n} d_{j}} .
$$

After weighing the criteria, problem options (crisis management candidate locations in the region) are prioritized using the MOORA method.
2.3. MOORA Method. MOORA is a multiobjective decisionmaking method introduced by Brauers and Zavadskas in 2006 [17]. In 2010, Azar and Rajabzadeh improved the method and added the complete multiplication form to it [18]. The steps for applying this method in the problems are as follows:

Step 1. The first step in the MOORA method is to construct a decision matrix for the problem. The criteria (goals) and options are listed in the column and row of the decision matrix, respectively. The decision matrix shows the performance of different options according to different criteria.

$$
\left[\begin{array}{cccc}
x_{11} & x_{12} & \cdots & x_{1 n} \\
x_{21} & x_{22} & \cdots & x_{2 n} \\
\vdots & \vdots & \cdots & \vdots \\
x_{m 1} & x_{m 2} & \cdots & x_{m n}
\end{array}\right]
$$

Step 2. Normalizing each column as follows:

$$
n_{i j}=\frac{x_{i j}}{\sum_{i=1}^{m} x_{i j}^{2}}, \quad \forall j .
$$

Step 3. Creating a harmonic decision matrix like the TOPSIS method, the weight of each criterion is multiplied by the normal decision matrix, and then a balanced normal decision matrix is formed.

Step 4. Selecting the optimal option from the following formula:

$$
y_{i}=\sum_{j=1}^{g} w_{j} x_{i j}^{*}-\sum_{j=g+1}^{n} w_{j} x_{i j}^{*}, \quad(j=1,2, \ldots, n) .
$$

2.4. PROMETHEE Method. The PROMETHEE 1 method performs a partial ranking, and the PROMETHEE 2 method performs a complete ranking. It was first developed by Brans in 1982 and was widely used in the early years [19]. A few years later, two new versions of PROMETHEE, PROMETHEE 3 (ranking by time intervals), and PROMETHEE 4 (continuous case) were developed [20]. One of the important advantages of the PROMETHEE method is the simplicity, clarity, and reliability of results. This method can perform the evaluation process on a limited set of alternatives as a partial or complete ranking. Suppose $A$ is a set of options from which to choose. Assume there is an effective $K$ criterion in the decision, $A \in a$; for each option, $F_{j}(a)$ represents the value of the criterion $j$ in option a. Ranking is done in three steps as follows:

Step 1. $P_{j}$ the preference function is assigned to each of the jth criteria. The value of $\operatorname{Pj}(a, b)$ is calculated for each option pair. If the relation $\mathrm{F}_{j}(a)=\mathrm{F}_{j}(b)$ is established, the value of $P_{j}(a \cdot b)$ becomes zero, and with increasing $\mathrm{F}_{j}(a)=\mathrm{F}_{j}(b)$, this value increases, and when the difference is equal to 1 , if it increases enough, the value of $P_{j}(a \cdot b)$ also reaches one. Different shapes can be assumed for the $P_{j}$ function, depending on how 
the jth criterion is modeled. The PROMETHEE method proposes six generalized criteria for the preference function to the decision-maker.

Step 2. The total preference $\pi(a, b)$ for each action is calculated on action (b). Although $\pi(a, b)$ is higher, action (a) is more preferable. $\pi(a, b)$ is calculated as follows [21]:

$$
\pi(a, b)=\sum_{j=1}^{\mathrm{K}} w j p j(a, b) ،\left(\sum_{j=1}^{\mathrm{K}} w j=1\right) .
$$

Step 3. $\pi(a, b)$ indicates the degree of preference of action $(a)$ over action $(b)[21,22] . \varnothing^{+}$is a positive current obtained from (11) and examines the degree of preference of $(a)$ over $n-1$ of the other action. This is the amount of power of action $(a)$. The positive preference flow or output current is as follows:

$$
\varnothing^{+}(a)=\frac{1}{n-1} \sum_{x \in A} \pi(x . a) .
$$

This flow indicates the priority of option $(a)$ over other options. The preference of other options over option $(a)$ is called input flow. The negative preference flow or input flow is as follows:

$$
\varnothing^{-}(a)=\frac{1}{n-1} \sum_{x \in A} \pi(x \cdot a) .
$$

This quantifies how a given action $(a)$ is being globally preferred by all the other actions. The smallest negative flow $\varnothing^{-}(a)$ represents the best action [23]. For the complete ranking of options, the net flow of ranking options is considered [23]:

$$
\varnothing(a)=\varnothing^{+}(a)-\varnothing^{-}(a) .
$$

The net flow score $(\varnothing(a))$ is computed as a difference between the positive flow and negative flow.

\section{Proposed Approach and Problem Statement}

In this research, a set of standard criteria for optimal location of relief centers as evaluation intervals and information layers in ArcGIS have been prepared. The weighting of criteria in the first phase was done by experts using the triangular fuzzy aggregation method. Then, the information layers are combined once by applying the weight of criteria and once without applying weight, and the optimal points are extracted. The Raster Calculator tool is used to merge layers so that all the layers were first gathered together and the final weightless map was produced. In the next step, we have multiplied each of the produced raster maps by their weight and combined them. Each point (weighted and nonweighted) is evaluated and scored against the criteria by GIS. After locating the proposed areas by GIS and observing unusable places in crisis (military centers and residential areas), in the next phase, 30 points of places were designated by the regional crisis management as post-crisis relief centers and identified by the GIS, and the problem was evaluated according to standard criteria. Then, the criteria were weighted by the entropy method, and the options were ranked by the MOORA method. Finally, due to the net input and output flows and the addition of constraints, optimal and efficient options were introduced. The performance of each of the options (options extracted by the GIS and selected options in the region) was evaluated according to their performance score. Due to incompatibilities between some research options, it may not be logical and possible to select some options at the same time. For this reason, there are 9 constraints for choosing the final optimal options. In this research, 2 constraints for the minimum and maximum options for selecting relief places and 7 other constraints for observing the standard distance set by experts have been considered. Figure 1 shows the general structure of the research.

In this study, after determining and evaluating the criteria, their weighting was done by the fuzzy aggregation method (by experts) and entropy method (point output information matrix) to determine the effect of each method on the results. Candidate points of the region extracted by the MOORA rank method were compared with the top points extracted from the GIS by the PROMETHEE method. This comparison was performed to evaluate and analyze the performance of each method to select relief centers in crises.

\section{Case Study}

The city of Tehran, located in the foothills of the Alborz Mountains range, has a high seismic risk and many active faults. Region 1 is located in the north and northeast of Tehran. This area is about 60 square kilometers. Relief centers are being set up to house the victims and people who lost their homes during the crisis. One of these crises is earthquakes. One of the secondary effects of earthquakes is liquefaction [24]. Liquidation causes severe damage to many structures, especially buildings [25]. The Japan International Cooperation Agency (JICA) has researched the Tehran earthquake. They have identified four-fault models that cause a lot of damage and loss, including the Ray fault model, Mosha fault model, North Tehran fault model, and floating model. One of the most important faults in the region is a North Tehran fault (more than $90 \mathrm{~km}$ ). North Tehran fault, the northern part of the city, is facing many seismic hazards and damages because the fault is located on the northern outskirts of the city. According to research by JICA, in North Tehran fault, in the worst case, 130,000 people or about $2 \%$ of Tehran's population will be killed. The loss ratio in the northern part of the city will be high in areas 1 to 5 . Also, the number of damages to buildings in this area is estimated at more than 60,000 buildings according to four fault models [26]. Therefore, in this research, we try to identify and evaluate the optimal places and areas for housing in crises. Table 1 shows the number and percentage of damage to buildings in area 1 based on each of the models [26]. 


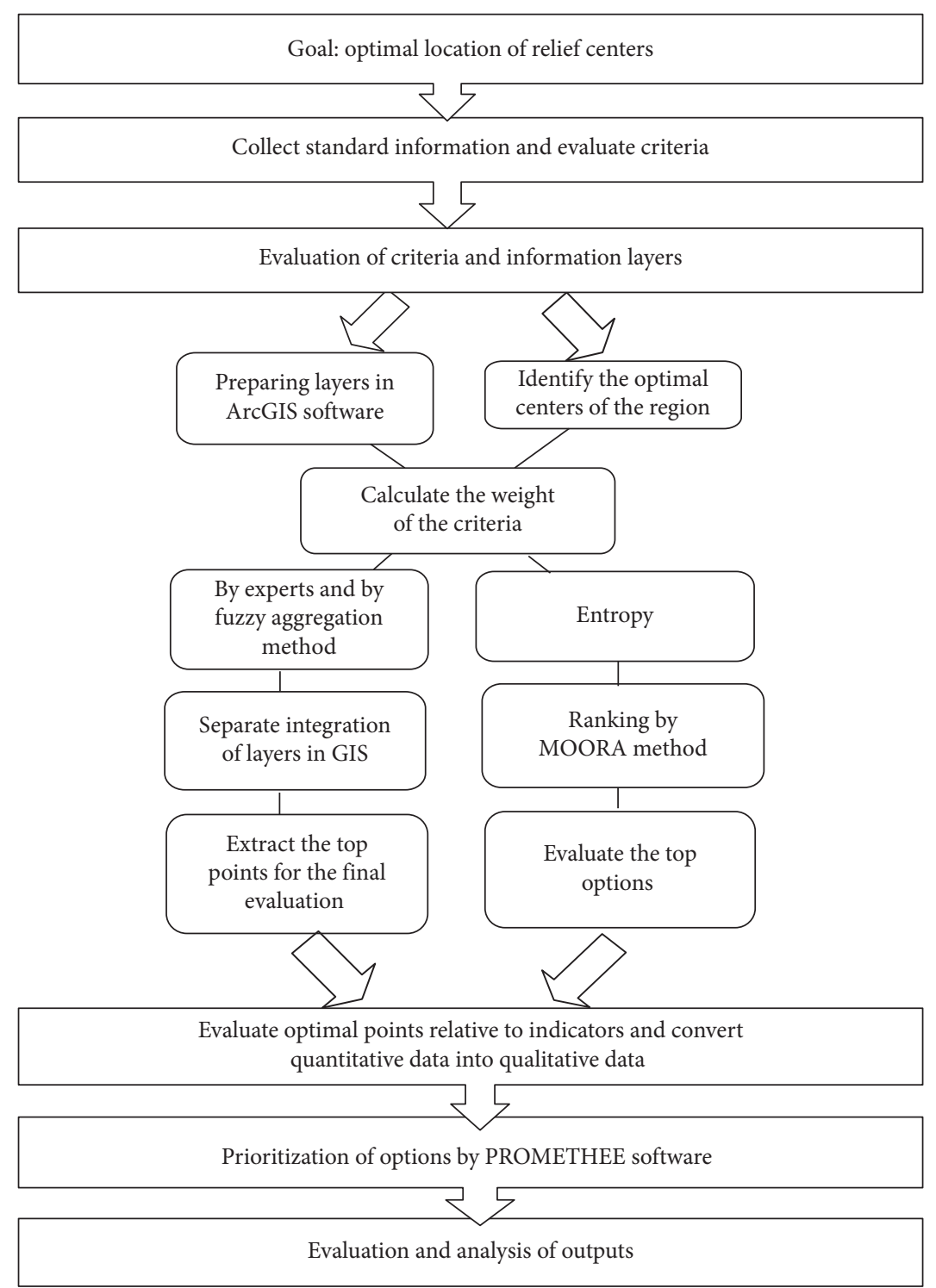

Figure 1: A schema of the proposed framework.

Table 1: Number and percentage of damages to buildings in Region 1.

\begin{tabular}{|c|c|c|c|c|c|c|c|c|c|}
\hline \multirow[b]{2}{*}{ Region } & \multicolumn{2}{|c|}{ Floating model } & \multicolumn{2}{|c|}{ Mosha fault model } & \multicolumn{2}{|c|}{ North Tehran fault model } & \multicolumn{2}{|c|}{ Ray fault model } & \multirow{2}{*}{$\begin{array}{c}\text { Total number of } \\
\text { damaged } \\
\text { buildings }\end{array}$} \\
\hline & Percentage & $\begin{array}{l}\text { Number of } \\
\text { buildings }\end{array}$ & Percentage & $\begin{array}{l}\text { Number of } \\
\text { buildings }\end{array}$ & Percentage & $\begin{array}{l}\text { Number of } \\
\text { buildings }\end{array}$ & Percentage & $\begin{array}{c}\text { Number of } \\
\text { buildings }\end{array}$ & \\
\hline 1 & 51.9 & 19.905 & 17.9 & 6.869 & 61.6 & 23.633 & 30.4 & 11.665 & 62.072 \\
\hline
\end{tabular}

\section{Data and Results}

Criteria based on previous studies and classification of these criteria have been considered in collaboration with crisis management experts. The research criteria are shown in Table 1, which are defined in two parts (compatible access and incompatible access). The evaluation criteria are as follows:

(1) Standard mode of each criterion in the range (Good)
(2) Better than the standard mode in the range (Very good)

(3) A little away from the standard mode in the range (Average)

(4) Slightly longer than standard in (Bad) range

(5) If it is too far from the standard range, it is in the (Very bad) range

Table 2 shows the classification and evaluation of criteria. 
TABLE 2: Classification and evaluation of criteria for locating relief centers in crises.

\begin{tabular}{|c|c|c|c|c|c|c|}
\hline & \multirow{2}{*}{ C } & \multicolumn{5}{|c|}{$A$} \\
\hline & & Very good & Good & Average & $\mathrm{Bad}$ & Very bad \\
\hline \multirow{11}{*}{ Compatible access } & Area & 3000 & $2000-3000$ & 2000 & $1000-2000$ & $0-1000$ \\
\hline & Worn texture & $0-100$ & $100-200$ & $200-300$ & $300-400$ & 400 \\
\hline & Main ways & $0-100$ & $100-200$ & $200-300$ & $300-400$ & 400 \\
\hline & Security & $0-200$ & $200-400$ & $400-600$ & $600-800$ & 800 \\
\hline & Slope percent & $1-4$ & $4-6$ & $6-10$ & $10-12$ & +12 \\
\hline & Hospital & $0-500$ & $500-1000$ & $1000-1500$ & $1500-2000$ & 2000 \\
\hline & Fire station & $0-500$ & $500-1000$ & $1000-1500$ & $1500-2000$ & 2000 \\
\hline & Population & 120 & $90-120$ & 60-90 & $30-60$ & $0-30$ \\
\hline & Health centers & $0-200$ & $200-500$ & $500-700$ & $700-1000$ & 1000 \\
\hline & Educational centers & $0-150$ & $150-300$ & $300-500$ & $500-700$ & 700 \\
\hline & Parks and gardens & $0-200$ & $200-400$ & $400-600$ & $600-1000$ & 1000 \\
\hline \multirow{7}{*}{ Incompatible access } & City gas station & 400 & $200-400$ & $100-200$ & $50-100$ & $0-50$ \\
\hline & CNG and fuel station & 400 & $200-400$ & $100-200$ & $50-100$ & $0-50$ \\
\hline & Wells and aqueducts & 300 & $200-300$ & $100-200$ & $50-100$ & $0-50$ \\
\hline & Electric post & 100 & $80-100$ & $60-80$ & $30-60$ & $0-30$ \\
\hline & Subway & 300 & $200-300$ & $100-200$ & $50-100$ & $0-50$ \\
\hline & Fault & 400 & $200-400$ & 200 & $100-200$ & $0-100$ \\
\hline & Rivers & 700 & $500-700$ & $200-500$ & $100-200$ & $0-100$ \\
\hline
\end{tabular}

Table 3 shows the corresponding triangular fuzzy scale, and Table 4 presents the fuzzy opinions of experts, respectively. Also, the calculated weight of the criteria is given in Table 5, where the highest weight is related to the indicators of proximity to hospitals, medical centers, and worn tissue (1.0) and the lowest weight is related to the indicators of proximity to educational centers and surface area (0.7).

\subsection{Layer Valuation and GIS Output Evaluation. A Geo-} graphic Information System (GIS) is a coherent system of hardware, software, and data that allows data entered into a computer to be stored, analyzed, transferred, evaluated, and retrieved as a map, tabular, and zoned information geographies to be published. With the help of GIS, all kinds of processing and analysis can be done with cost and time savings [27]. GIS, with its capabilities in collecting, storing, retrieving, controlling, processing, analyzing, modeling, and displaying geographic data, can be a powerful tool in the hands of managers and planners for optimal use of resources [28]. In this study, the information layer was stored using the capabilities of the GIS. For uniformity and impact, the layers are evaluated as numerical intervals based on the buffer created in ArcGIS software. The following maps including a map of distance to the river (Figure 2), map of slope percentage (Figure 3), map of population density (Figure 4), map of distance to the gas station (Figure 5), map of distance to parks (Figure 6), and map of distance to the fire station (Figure 7) are an example of the criteria layers related to this research.

Figure 8 shows the favorable and unfavorable areas of the region for the establishment of relief centers. The blue area indicates favorable areas, and the red area indicates unfavorable areas.

After weighing the criteria, using GIS, and preparing information layers, first, the layers are matched without applying the weight of the indicators, and in the next step by
TABle 3: Linguistics variables of fuzzy for the weight of each criterion.

\begin{tabular}{lccc}
\hline VH & 0.75 & 1 & 1 \\
$\mathrm{H}$ & 0.5 & 0.75 & 1 \\
$\mathrm{M}$ & 0.25 & 0.5 & 0.75 \\
$\mathrm{~L}$ & 0 & 0.25 & 0.5 \\
$\mathrm{VL}$ & 0 & 0 & 0.25 \\
\hline
\end{tabular}

TABLE 4: Evaluated matrix of research criteria by experts.

\begin{tabular}{|c|c|c|c|c|c|c|c|c|c|}
\hline & & TM1 & & & TM2 & & & TM3 & \\
\hline Area & 0.25 & 0.5 & 0.75 & 0 & 0.25 & 0.5 & 0 & 0.25 & 0.5 \\
\hline Iain ways & & & 1 & & 0.5 & & 0.5 & .75 & 1 \\
\hline & & 0.75 & 1 & .75 & 1 & 1 & 0.5 & 0.75 & 1 \\
\hline & 0.25 & 0.5 & 0.75 & 0.25 & 0.5 & 0.75 & 0.5 & 0.75 & 1 \\
\hline tation & 0.25 & 0.5 & 0.75 & 0.25 & 0.5 & 0.75 & 0.5 & 0.75 & 1 \\
\hline & 0 & 0.25 & 0.5 & 0.25 & 0.5 & 0.75 & 0.5 & 0.75 & 1 \\
\hline & 0.5 & 0.75 & 1 & 0.75 & 1 & 1 & 0.75 & 1 & 1 \\
\hline & 0.25 & 0.5 & 0.75 & 0.25 & 0.5 & 0.75 & 0.25 & 0.5 & 0.75 \\
\hline & 0.25 & 0.5 & 0.75 & 0.25 & 0.5 & 0.75 & 0.75 & 1 & 1 \\
\hline & 0.25 & 0.5 & 0.75 & 0 & 0.25 & 0.5 & 0.25 & 0.5 & 0.75 \\
\hline & & 0.5 & 0.75 & 0.25 & 0.5 & 0.75 & 0.5 & 0.75 & 1 \\
\hline & 0.75 & 1 & 1 & 0.5 & 0.75 & 1 & 0.5 & 0.75 & 1 \\
\hline h & 0.5 & 0.75 & 1 & 0.75 & 1 & 1 & 0.75 & 1 & 1 \\
\hline & 0.5 & 0.75 & 1 & 0.5 & 0.75 & 1 & 0.25 & 0.5 & 0.75 \\
\hline ducational & 0 & 0.25 & 0.5 & 0 & 0.25 & 0.5 & 0.25 & 0.5 & 0.75 \\
\hline & 0.25 & 0.5 & 0.75 & 0.25 & 0.5 & 0.75 & 0.25 & 0.5 & 0.75 \\
\hline & 0 & 0.25 & 0.5 & 0.25 & 0.5 & 0.75 & 0.25 & 0.5 & 0.75 \\
\hline $\begin{array}{l}\text { Worn } \\
\text { texture }\end{array}$ & 0.5 & 0.75 & 1 & 0.75 & 1 & 1 & 0.75 & 1 & 1 \\
\hline
\end{tabular}


TABLE 5: Weight of criteria obtained by experts.

\begin{tabular}{lcc}
\hline Criteria & Weight & Final normal weight \\
\hline Area & 0.33 & 0.4 \\
Main ways & 0.67 & 0.8 \\
Security & 0.78 & 0.9 \\
City gas station & 0.58 & 0.7 \\
CNG station & 0.58 & 0.7 \\
Percent slope & 0.50 & 0.6 \\
Hospital & 0.83 & 1.0 \\
Fire station & 0.50 & 0.6 \\
Electricity post & 0.58 & 0.7 \\
Population & 0.42 & 0.5 \\
Subway & 0.58 & 0.7 \\
Fault & 0.78 & 0.9 \\
Health centers & 0.83 & 1.0 \\
Rivers & 0.67 & 0.8 \\
Educational centers & 0.33 & 0.4 \\
Parks and gardens & 0.50 & 0.6 \\
Wells and aqueducts & 0.42 & 0.5 \\
Worn texture & 0.83 & 1.0 \\
\hline
\end{tabular}

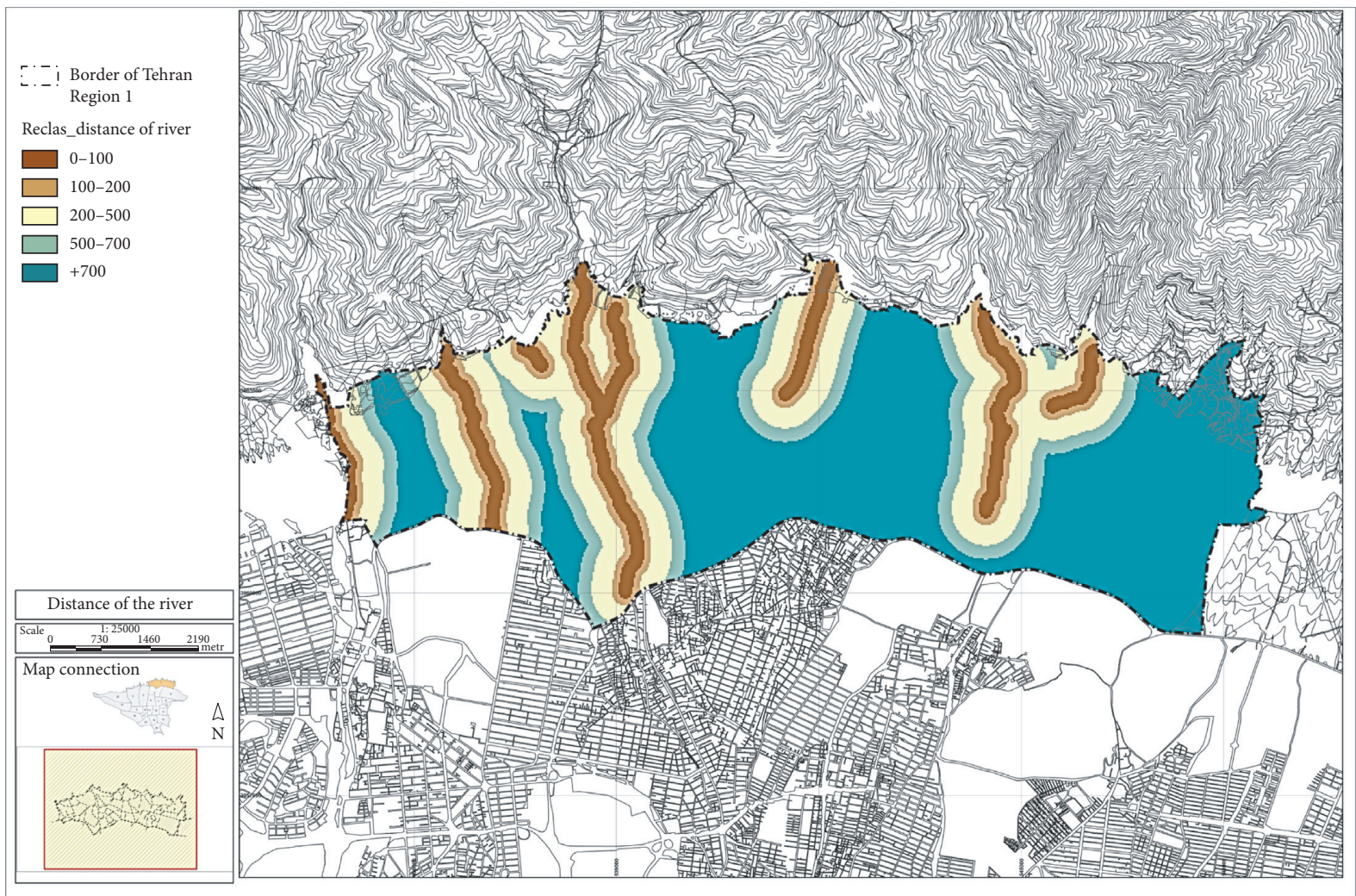

FIgURe 2: Distance to the river.

applying the weight of the indicators in ArcGIS software, the proposed optimal points among the optimal areas are extracted in the area. Figures 9 and 10 show the proposed points extracted for the construction of relief bases in both cases (by applying the weight of the criteria and without applying the weight of the criteria).
5.2. Evaluation and Feasibility of the Proposed Optimal Points. After combining the information layers and determining the proposed optimal points by the GIS, the proposed points are evaluated in terms of the location of each extracted optimal area relative to the indicators evaluated in Table 1. As shown in Figures 9 and 10, the proposed optimal points of the GIS 


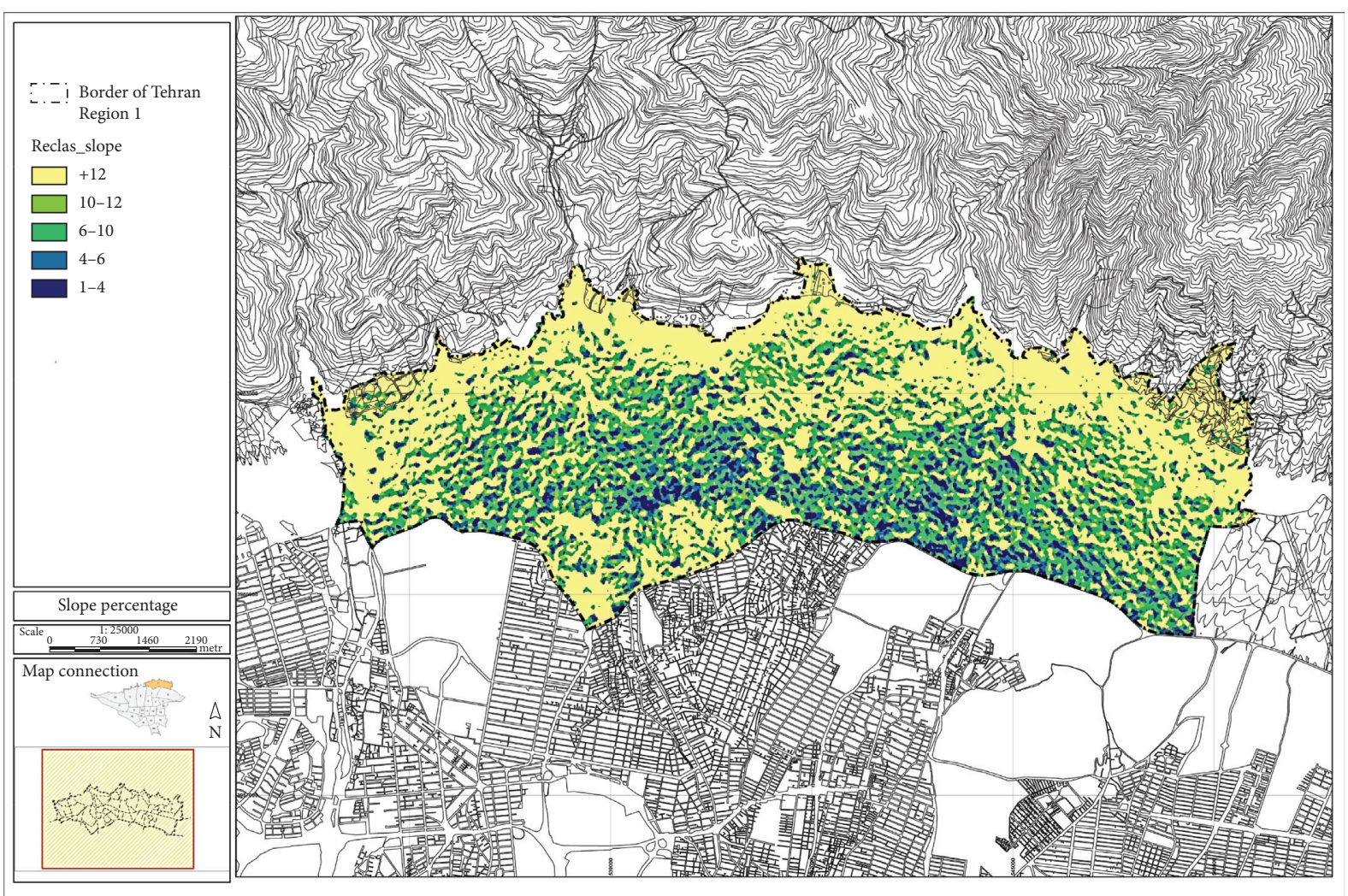

Figure 3: Slope percentage.

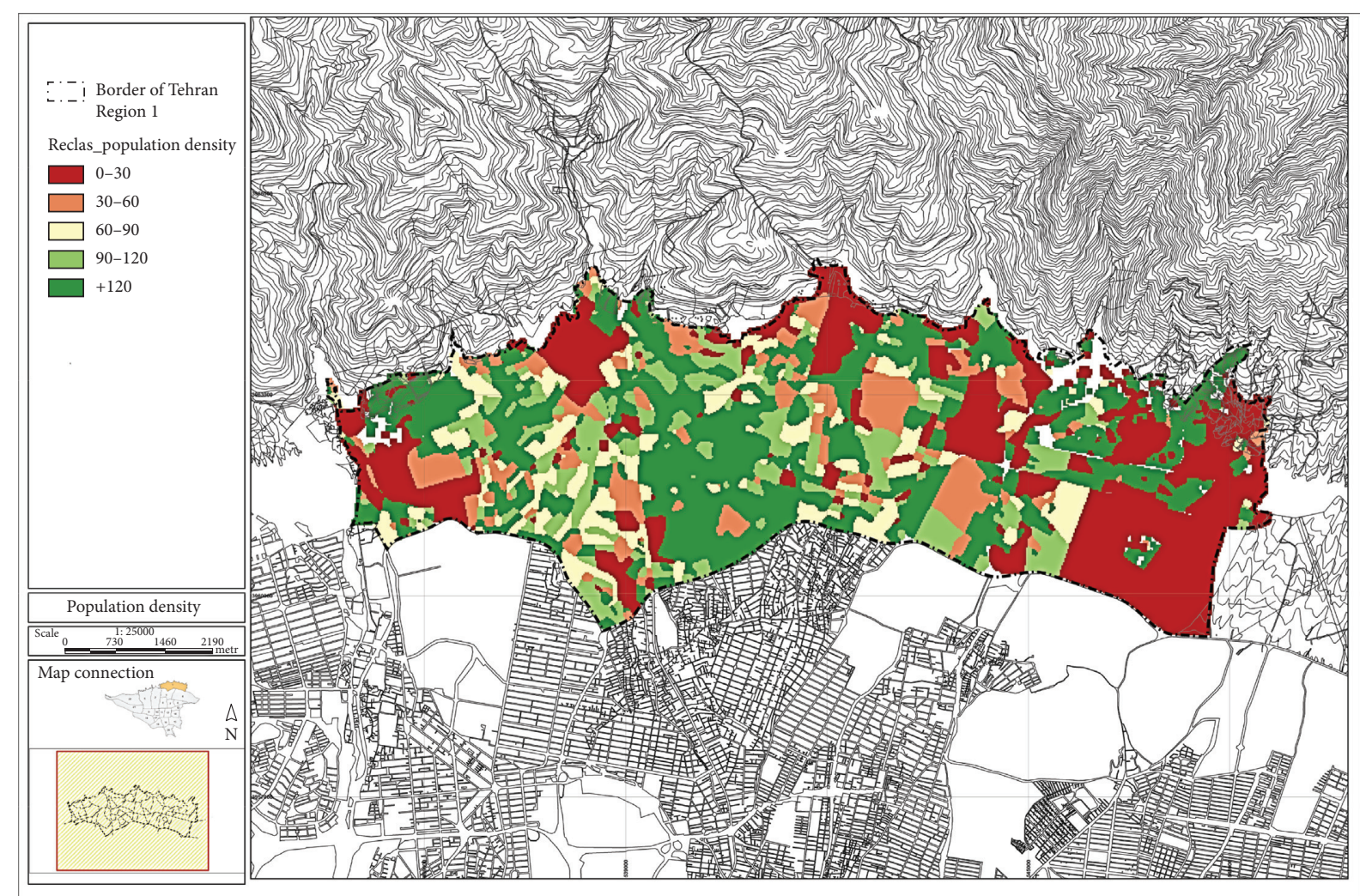

Figure 4: Population density. 


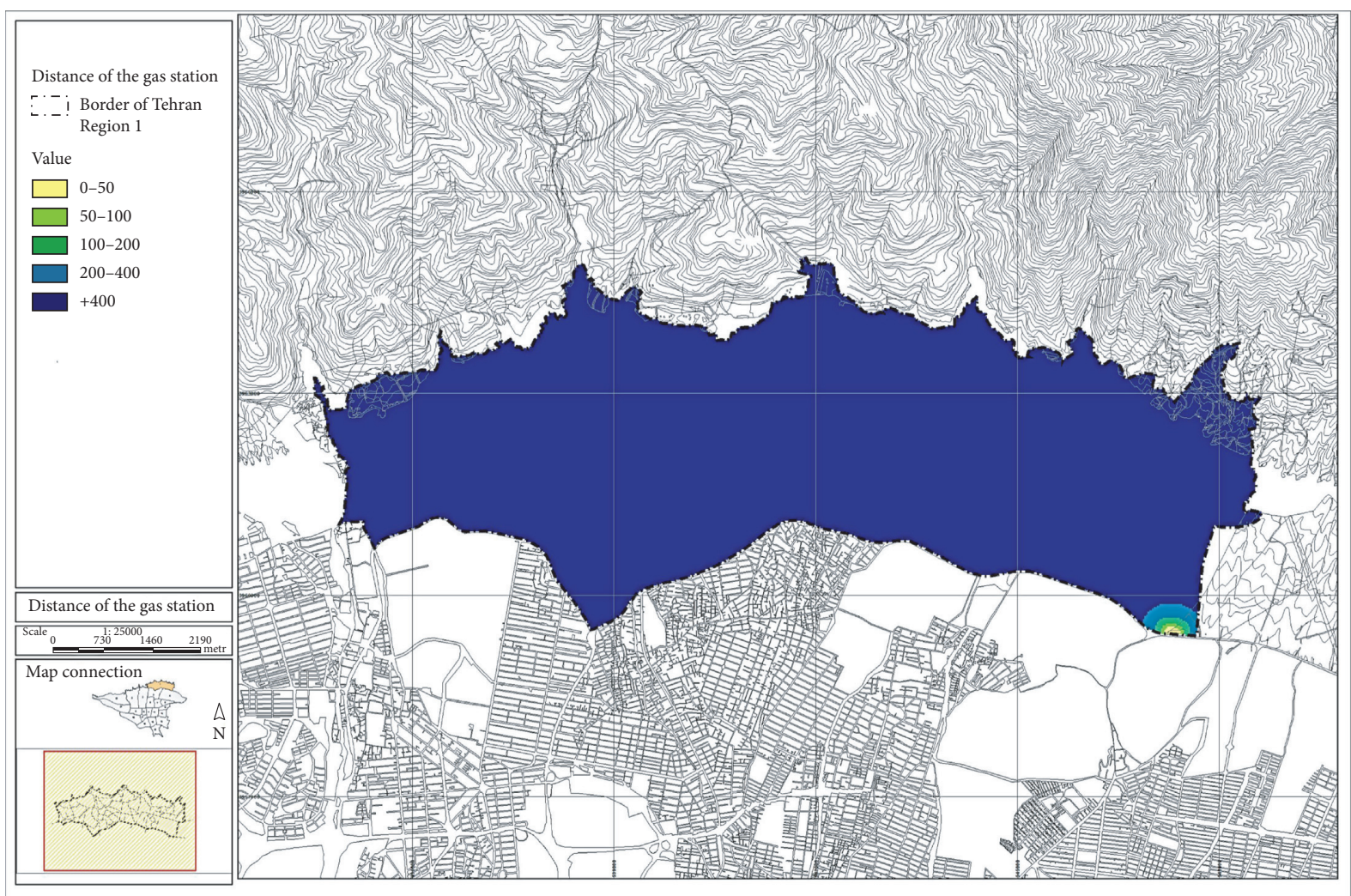

Figure 5: Distance to the gas station.

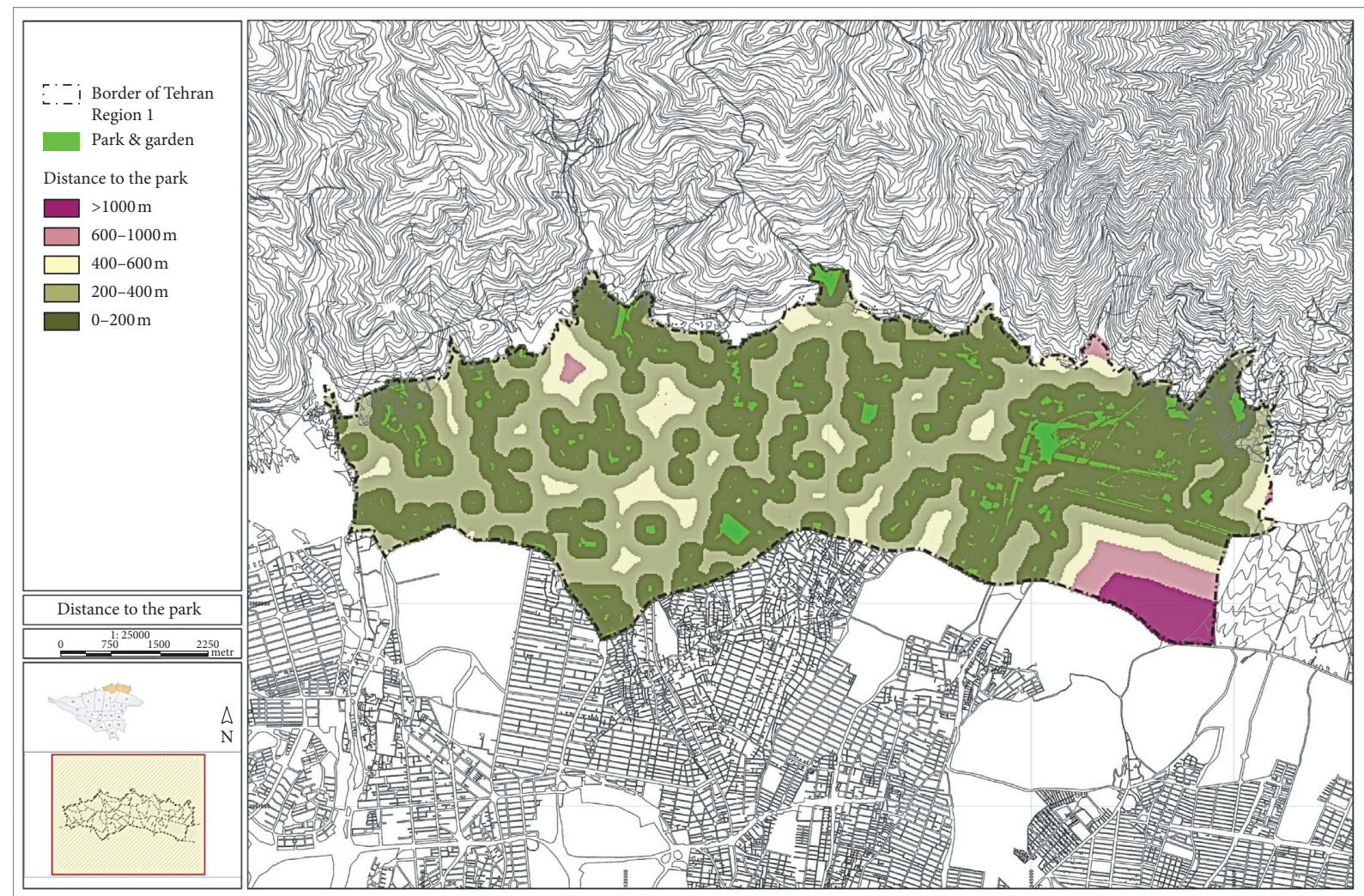

Figure 6: Distance to parks. 


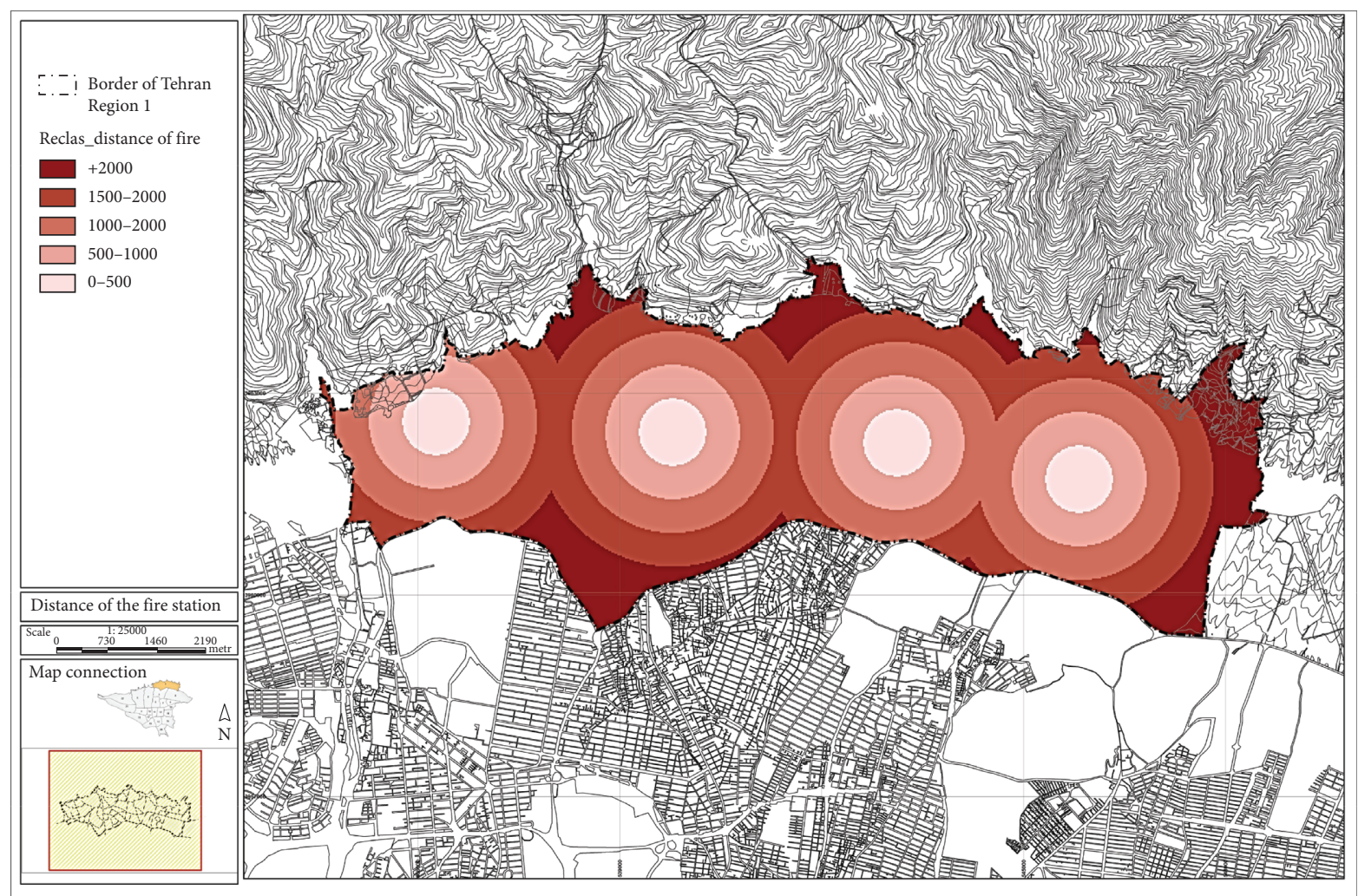

Figure 7: Distance to the fire station.

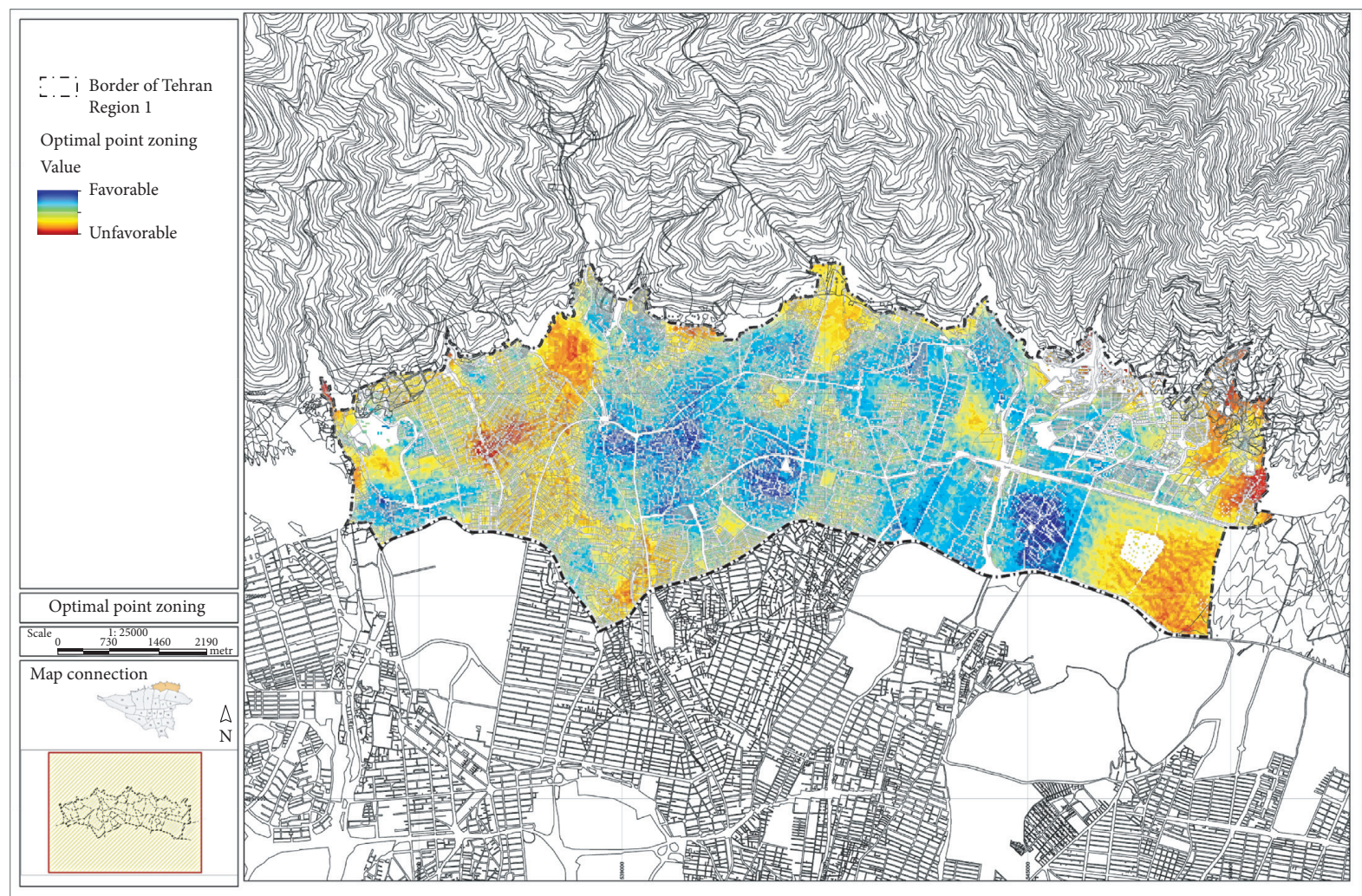

FIGURE 8: Favorable and unfavorable areas for the construction of relief centers. 


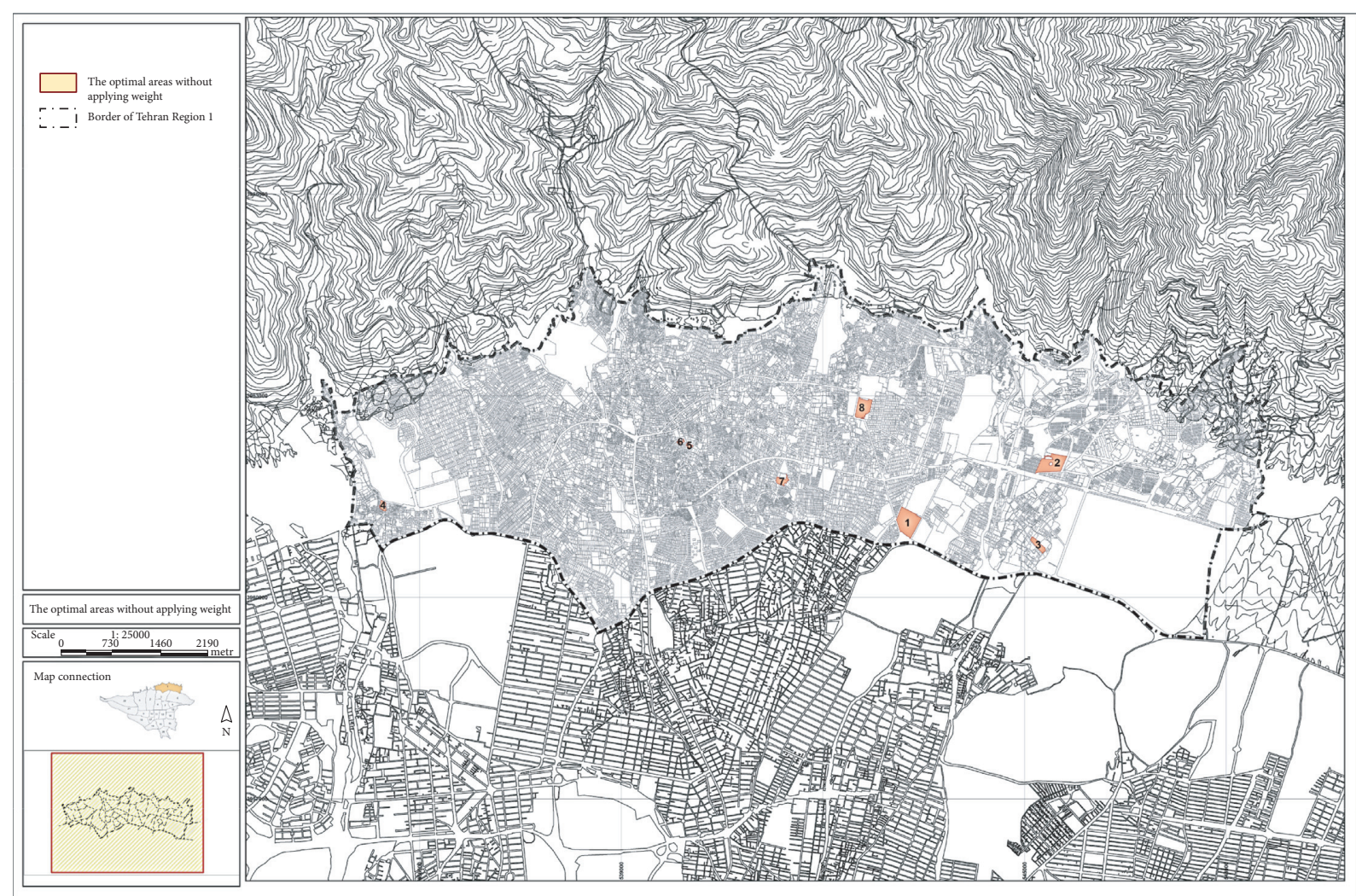

FIGURE 9: Optimal areas extracted by GIS without applying weight.

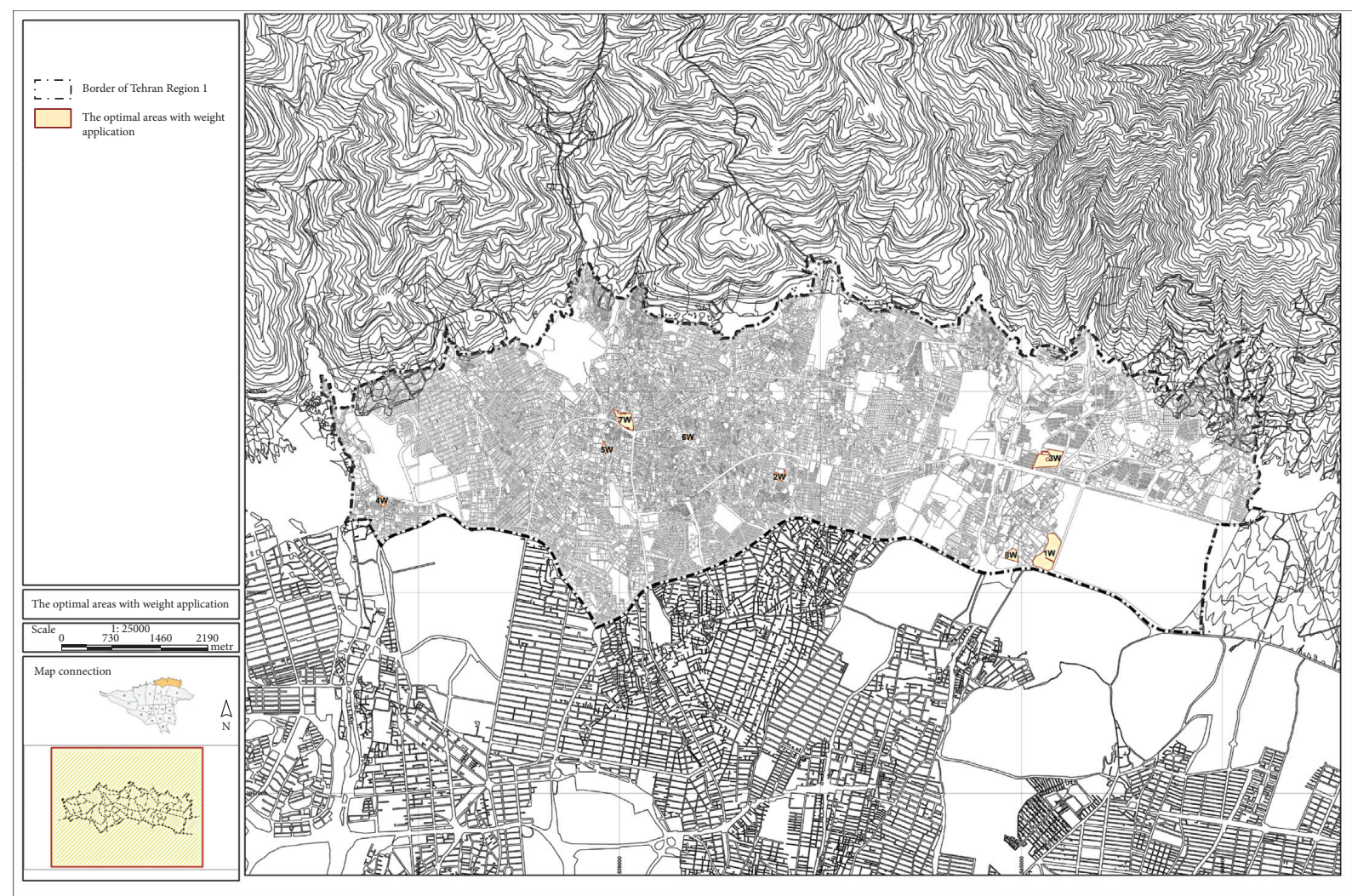

FIGURE 10: Optimal areas extracted by GIS by applying weight. 
with the application of criteria weights (PW1, PW2, PW3, PW4, PW5, PW6, PW7, and PW8) and without the application of criteria weights (P1, P2, P3, P4, P5, P6, P7, and P8) are different. Table 6 shows the results of the evaluation of points without assigned weight (eight optimal regions obtained in Figure 9), and Table 7 shows the results of the evaluation of points with assigned weight (eight optimal regions obtained in Figure 10). For example, the results of evaluating the optimal points extracted without applying weights (see Figure 9) to the distance criteria from the fault were as follows: points p1, p2, p3, p4, p7, and p8 in the range above $400 \mathrm{~m}$, and point p6 and p5 in the range of 400-200 were placed. Also, the results of evaluating the optimal points introduced by applying the weight of the indicators (see Figure 9) were as follows: PW1, PW2, PW3, PW4, and PW8 in the range above 400 meters, and PW5 and PW6 in the range of 400-200 and PW9 in the range of 0-100 were placed. The evaluation results of other optimal points extracted are shown in Tables 6 and 7.

Afterward, the criteria have been qualitatively evaluated (Very bad; Good; Average; Bad; Very good). Very good has the highest score and Very bad has the lowest score. Each of these points (points with the weight of experts and points without the weight of experts) is placed in one of the scoring points after evaluation by the GIS. For example, point PW1, after evaluation by the Geographic Information System (GIS), is in the range of 0-200 in terms of security criteria, which according to the classification considered in Table 2 is qualitatively in the range of Very good. Also, if we examine point P1 with the same criteria, it is shown in Table 6 that this point is in the range of 200-400, which according to the classification considered in Table 1 will be in the range of Good.

\subsection{Feasibility Study of the Proposed Areas of the GIS and Relief} Centers in the Case Study. Using Google Earth, the output of the optimal areas proposed for the establishment of relief centers in times of crisis has been examined (see Figure 11). As can be seen in Figures 12 and 13, some of the selected areas of the GIS (optimal proposed areas of Figures 9 and 10) have been military or residential. It will not be possible to use these places as postcrisis relief centers.

Usually, after an earthquake, to create safe conditions for residents and citizens and get them out of dangerous conditions, safe evacuation operations are carried out. Safe evacuation centers include all safe evacuation sites and spaces where people can be accommodated if needed. They use basic facilities to meet their needs (for 72 hours). The Tehran Crisis Management Organization has identified suitable locations in all 22 districts of Tehran to use these shelters in times of crisis. Figure 14 shows the location of these places, which are mostly stadiums and parks in the area.

\section{Evaluation of Calculation Results}

Then, 30 locations determined by Tehran Crisis Management in the study area were identified and evaluated by the
GIS according to the standard criteria of this study (Table 2). Most of these places are stadiums, universities, and parks that cover almost all parts of the region. The results of the evaluation of these places by the GIS are shown in Table 8 .

After evaluating 30 relief sites considered by the regional crisis management and forming a pairwise comparison matrix, the criteria were weighted and then prioritized. Table 9 shows the weight of the criteria calculated by the entropy method. As can be seen in Table 9, the criterion of distance from the river and distance from the main roads has the highest weight $(0.0589,0.0576)$ and the criteria of worn texture and land slope have the lowest weight $(0.0470$, 0.0514).

Problem options are prioritized according to the MOORA method (see Table 10). As can be seen, the performance score (Yi) of Morvarid Park, Gol Mohammadi Park, and Negin Park is higher than that of other options, so these options ranked first to third.

After ranking the proposed locations in the area for temporary accommodation, the top eight locations were selected and quantitative values were converted to qualitative (according to the information in Table 2) to compare and evaluate these options with the proposed optimal points of GIS. After evaluating the proposed areas by GIS in both modes (with the weight of experts and without the weight of experts) and the places determined by the Crisis Management of Region 1, the final optimal options with the PROMETHEE method were compared and evaluated. In the options evaluation step, the obtained qualitative values are considered a pairwise comparison matrix for options and criteria. Table 11 shows the result of flow evaluation, which shows the values of positive $\varnothing^{+}$, negative $\varnothing^{-}$, and net $\varnothing$ Flows. As can be seen in Table 11, P5 with a net flow of 0.1232 , P6 with a net flow of 0.1208 , and PW8 with a net flow of 0.1159 were ranked first to third in the PROMETHEE rankings. Also, Morvarid Park with a net flow of -0.1860 , Shadi Park with a net flow of -0.1715 , and Aseman Park with a net flow of -0.1570 had the worst performance. Table 11 shows the PROMETHEE ranking results of options.

In Figure 15, GAIA diagram shows the options. The length of an axis also indicates the relative strength of that criterion. A longer axis indicates a more important criterion. On the other hand, the direction of an axis indicates where the best possible options for this criterion are located. In the GAIA form, options that are similar to each other are closer to each other, and options that conflict with each other are farther apart. Criteria that have similar preferences are in the same direction, and criteria that have conflicting preferences are in different directions. For example, the PW1 option is in line with the percentage of slope and distance from worn texture, which shows good performance compared with these indicators. This option has performed very poorly in terms of the criteria of main roads, distance from the subway, and distance from parks (due to being in the opposite direction of these criteria). As can be seen, the proposed locations in the region are scattered and far from the axes of the criteria, and this poor performance has led to a lower ranking than other options. 
TABLE 6: Evaluation of optimal points according to criteria (without applying normalized weight).

\begin{tabular}{|c|c|c|c|c|c|c|c|c|}
\hline \multirow{2}{*}{ Optimal points } & \multicolumn{8}{|c|}{ Criteria } \\
\hline & $\mathrm{P}_{1}$ & $\mathrm{P}_{2}$ & $\mathrm{P}_{3}$ & $\mathrm{P}_{4}$ & $\mathrm{P}_{5}$ & $\mathrm{P}_{6}$ & $\mathrm{P}_{7}$ & $\mathrm{P}_{8}$ \\
\hline Area & $\begin{array}{l}\text { More than } \\
3000\end{array}$ & $\begin{array}{l}\text { More than } \\
3000\end{array}$ & $\begin{array}{l}\text { More than } \\
3000\end{array}$ & $\begin{array}{l}\text { More than } \\
3000\end{array}$ & $\begin{array}{l}\text { More than } \\
3000\end{array}$ & $\begin{array}{l}\text { More than } \\
3000\end{array}$ & $\begin{array}{l}\text { More than } \\
3000\end{array}$ & $\begin{array}{l}\text { More than } \\
3000\end{array}$ \\
\hline Worn texture & $\begin{array}{l}\text { More than } \\
\quad 400\end{array}$ & $\begin{array}{l}\text { More than } \\
\quad 400\end{array}$ & 200_300 & $0-100$ & 100_200 & 100_200 & 100_200 & $\begin{array}{l}\text { More than } \\
400\end{array}$ \\
\hline Main ways & $0-100$ & $200-300$ & $200-300$ & 0-100 & $0-100$ & $100-200$ & $100-200$ & $100-200$ \\
\hline Security & $200-400$ & $400-600$ & $200-400$ & $\begin{array}{l}\text { More than } \\
\quad 800\end{array}$ & $200-400$ & $0-200$ & $200-400$ & $0-200$ \\
\hline Gas station & $200-400$ & $\begin{array}{l}\text { More than } \\
\quad 400\end{array}$ & $\begin{array}{l}\text { More than } \\
\quad 400\end{array}$ & $\begin{array}{l}\text { More than } \\
\quad 400\end{array}$ & $\begin{array}{l}\text { More than } \\
\quad 400\end{array}$ & $\begin{array}{l}\text { More than } \\
\quad 400\end{array}$ & $\begin{array}{l}\text { More than } \\
\quad 400\end{array}$ & $\begin{array}{l}\text { More than } \\
\quad 400\end{array}$ \\
\hline CNG station & $\begin{array}{l}\text { More than } \\
\quad 400\end{array}$ & $\begin{array}{l}\text { More than } \\
\quad 400\end{array}$ & $\begin{array}{l}\text { More than } \\
\quad 400\end{array}$ & $\begin{array}{l}\text { More than } \\
\quad 400\end{array}$ & $\begin{array}{l}\text { More than } \\
\quad 400\end{array}$ & $\begin{array}{l}\text { More than } \\
\quad 400\end{array}$ & $\begin{array}{l}\text { More than } \\
\quad 400\end{array}$ & $\begin{array}{l}\text { More than } \\
\quad 400\end{array}$ \\
\hline Percent slope & $6-10$ & 6-10 & 6-10 & More than 12 & $\begin{array}{c}\text { More than } \\
12\end{array}$ & $1-4$ & $1-4$ & $\begin{array}{c}\text { More than } \\
12\end{array}$ \\
\hline $\begin{array}{l}\text { Wells and } \\
\text { aqueducts }\end{array}$ & $200 \_300$ & $\begin{array}{l}\text { More than } \\
\quad 300\end{array}$ & $\begin{array}{l}\text { More than } \\
300\end{array}$ & $\begin{array}{l}\text { More than } \\
300\end{array}$ & $\begin{array}{l}\text { More than } \\
300\end{array}$ & $\begin{array}{l}\text { More than } \\
\quad 300\end{array}$ & 200_300 & $\begin{array}{l}\text { More than } \\
300\end{array}$ \\
\hline Hospital & 500_1000 & 500_1000 & 1000_1500 & 500_1000 & 500_1000 & 500_1000 & 1000_1500 & 500_1000 \\
\hline Fire station & 1000_1500 & 0_500 & 1000_1500 & 1000_1500 & 0_500 & 0_500 & 1500_2000 & 500_1000 \\
\hline Electricity post & $\begin{array}{l}\text { More than } \\
100\end{array}$ & $\begin{array}{l}\text { More than } \\
100\end{array}$ & $\begin{array}{l}\text { More than } \\
100\end{array}$ & $\begin{array}{l}\text { More than } \\
100\end{array}$ & $\begin{array}{c}\text { More than } \\
100\end{array}$ & $\begin{array}{l}\text { More than } \\
100\end{array}$ & $\begin{array}{l}\text { More than } \\
100\end{array}$ & $\begin{array}{c}\text { More than } \\
100\end{array}$ \\
\hline Population & $\begin{array}{l}\text { More than } \\
120\end{array}$ & $90-120$ & 90_120 & $\begin{array}{c}\text { More than } \\
120\end{array}$ & $\begin{array}{c}\text { More than } \\
120\end{array}$ & $30 \_60$ & 0_30 & $30 \_60$ \\
\hline Subway & $\begin{array}{l}\text { More than } \\
\quad 300\end{array}$ & $50-100$ & $\begin{array}{l}\text { More than } \\
300\end{array}$ & $\begin{array}{l}\text { More than } \\
300\end{array}$ & $\begin{array}{l}\text { More than } \\
\quad 300\end{array}$ & $\begin{array}{l}\text { More than } \\
\quad 300\end{array}$ & $\begin{array}{l}\text { More than } \\
300\end{array}$ & $\begin{array}{c}\text { More than } \\
300\end{array}$ \\
\hline Fault & $\begin{array}{l}\text { More than } \\
\quad 400\end{array}$ & $\begin{array}{l}\text { More than } \\
\quad 400\end{array}$ & $\begin{array}{l}\text { More than } \\
\quad 400\end{array}$ & $\begin{array}{l}\text { More than } \\
\quad 400\end{array}$ & $200-400$ & $200-400$ & $\begin{array}{l}\text { More than } \\
\quad 400\end{array}$ & $\begin{array}{l}\text { More than } \\
\quad 400\end{array}$ \\
\hline Health centers & $\begin{array}{l}\text { More than } \\
1000\end{array}$ & $700-1000$ & $0-200$ & $200-500$ & $700-1000$ & $700-1000$ & 0-200 & $\begin{array}{c}\text { More than } \\
1000\end{array}$ \\
\hline Rivers & $\begin{array}{l}\text { More than } \\
\quad 700\end{array}$ & 500_700 & $\begin{array}{l}\text { More than } \\
\quad 700\end{array}$ & $200 \_500$ & $\begin{array}{l}\text { More than } \\
\quad 700\end{array}$ & $\begin{array}{l}\text { More than } \\
\quad 700\end{array}$ & $\begin{array}{l}\text { More than } \\
\quad 700\end{array}$ & $\begin{array}{l}\text { More than } \\
\quad 700\end{array}$ \\
\hline $\begin{array}{l}\text { Educational } \\
\text { centers }\end{array}$ & 0_150 & 0_150 & 150_300 & 150_300 & 300_500 & 300_500 & 0_150 & 500_700 \\
\hline $\begin{array}{l}\text { Parks and } \\
\text { gardens }\end{array}$ & 0_200 & 0_200 & 0_200 & 0_200 & 0_200 & 0_200 & 0_200 & 0_200 \\
\hline
\end{tabular}

Among the research criteria, incompatible access criteria (criteria in Table 2) must observe the standard distance set by crisis management experts. For example, relief centers must be 400 meters away from the city gas station; otherwise, they will not be eligible for use as relief centers (even if they perform well in other criteria). PROMETHEE V selects the optimal options based on a 0 -1 linear program in which the objective function maximizes the sum of the net flow points (Phi). For each constraint, it is possible to enter the coefficients and specify the type of constraint $(\leq,=$ or $\geq)$. Table 12 sets the limits and shows the optimal options offered by PROMETHEE V. The "Optimal" column displays the optimal solution. The "Total" rows show the value of the objective function (i.e., the sum of the net flow scores of the selected actions) for both selections. PROMETHEE V offers P1, P2, P3, P5, P6, PW1, PW2, PW3, PW4, PW6, PW8, and Niavaran Park as optimal options for the overall flow of 0.8671 .

Figure 16 shows the efficiency of research options. This figure is a two-dimensional representation of the input and output flows. An efficiency frontier is drawn in red. Efficient options with different functions are on the line. Higher net flows of an action's outputs and lower net flows of its inputs are better. For instance, option PW7 has a high input flow and higher output flow. The other actions lag behind the efficient frontier. Finally, considering the amount of net flow $(\varnothing)$ and the performance score obtained for each of the options, the overall performance of the options in each optimal location extraction method is evaluated and shown in Figure 17. As can be seen, the performance of points without applying weights is $37 \%$ and with applying weights is $36 \%$ and the performance of places designated by crisis management is $27 \%$. The reason for the poor performance of the places in the region can be considered their poor performance in some standard criteria such as distance to main roads, distance to the river, and safety, which have been among the important criteria of the issue. The difference between optimal options and efficient options is in their evaluation process. The basis of the PROMETHEE $\mathrm{V}$ rating is the full rating (PROMETHEE II), which, by adding additional constraints to the multicriteria net flow rating $f$ (Phi), provides a global assessment of the measures taking into account all criteria. Efficient options are the result of comparing the input and output streams of the criteria classification. This is similar to the input/output model used in data envelopment analysis (DEA). When measuring the 
TABLE 7: Evaluation of optimal points according to the criteria (by applying normalized weight).

\begin{tabular}{|c|c|c|c|c|c|c|c|c|}
\hline \multirow{2}{*}{ Optimal points } & \multicolumn{8}{|c|}{ Criteria } \\
\hline & $\mathrm{P}_{\mathrm{W} 1}$ & $\mathrm{P}_{\mathrm{W} 2}$ & $\mathrm{P}_{\mathrm{W} 3}$ & $\mathrm{P}_{\mathrm{W} 4}$ & $\mathrm{P}_{\mathrm{W} 5}$ & $\mathrm{P}_{\mathrm{W} 6}$ & $\mathrm{P}_{\mathrm{W} 7}$ & $\mathrm{P}_{\mathrm{W} 8}$ \\
\hline Area & $\begin{array}{l}\text { More than } \\
3000\end{array}$ & $\begin{array}{l}\text { More than } \\
3000\end{array}$ & $\begin{array}{l}\text { More than } \\
3000\end{array}$ & $\begin{array}{l}\text { More than } \\
3000\end{array}$ & $\begin{array}{l}\text { More than } \\
3000\end{array}$ & $\begin{array}{l}\text { More than } \\
3000\end{array}$ & $\begin{array}{l}\text { More than } \\
3000\end{array}$ & $\begin{array}{c}\text { More than } \\
3000\end{array}$ \\
\hline Worn texture & $\begin{array}{l}\text { More than } \\
\quad 400\end{array}$ & $100-200$ & $0-100$ & $0-100$ & $100-200$ & 0_100 & 0_100 & $\begin{array}{c}\text { More than } \\
\quad 400\end{array}$ \\
\hline Main ways & 200_300 & $100-200$ & 200_300 & $0-100$ & 200_300 & 100_200 & 100_200 & 100_200 \\
\hline Security & $0-200$ & $200-400$ & $600-800$ & $\begin{array}{l}\text { More than } \\
\quad 800\end{array}$ & $400-600$ & $200-400$ & $0-200$ & $0-200$ \\
\hline Gas station & $\begin{array}{l}\text { More than } \\
\quad 400\end{array}$ & $\begin{array}{l}\text { More than } \\
\quad 400\end{array}$ & $\begin{array}{l}\text { More than } \\
\quad 400\end{array}$ & $\begin{array}{l}\text { More than } \\
\quad 400\end{array}$ & $\begin{array}{l}\text { More than } \\
\quad 400\end{array}$ & $\begin{array}{l}\text { More than } \\
\quad 400\end{array}$ & $\begin{array}{l}\text { More than } \\
\quad 400\end{array}$ & $\begin{array}{l}\text { More than } \\
\quad 400\end{array}$ \\
\hline CNG station & $\begin{array}{l}\text { More than } \\
\quad 400\end{array}$ & $\begin{array}{l}\text { More than } \\
\quad 400\end{array}$ & $\begin{array}{l}\text { More than } \\
\quad 400\end{array}$ & $\begin{array}{c}\text { More than } \\
400\end{array}$ & $\begin{array}{l}\text { More than } \\
\quad 400\end{array}$ & $\begin{array}{l}\text { More than } \\
\quad 400\end{array}$ & $\begin{array}{l}\text { More than } \\
\quad 400\end{array}$ & $\begin{array}{c}\text { More than } \\
\quad 400\end{array}$ \\
\hline Percent slope & 6_10 & 1_4 & 6_10 & More than 12 & 6_10 & 1_4 & 6_10 & 1_4 \\
\hline $\begin{array}{l}\text { Wells and } \\
\text { aqueducts }\end{array}$ & $\begin{array}{l}\text { More than } \\
\quad 300\end{array}$ & $200-300$ & $\begin{array}{c}\text { More than } \\
300\end{array}$ & $\begin{array}{c}\text { More than } \\
300\end{array}$ & $\begin{array}{l}\text { More than } \\
300\end{array}$ & $\begin{array}{c}\text { More than } \\
300\end{array}$ & $\begin{array}{l}\text { More than } \\
\quad 300\end{array}$ & $\begin{array}{c}\text { More than } \\
300\end{array}$ \\
\hline Hospital & 1000_1500 & 1000_15000 & 500_1000 & 500_1000 & $0 \_500$ & 500_1000 & $0 \_500$ & 500_1000 \\
\hline Fire station & 1000_1500 & $1500-2000$ & $1000-1500$ & 1000_1500 & 1000_1500 & 0_500 & 500_1000 & 1000_1500 \\
\hline Electricity post & $\begin{array}{l}\text { more than } \\
100\end{array}$ & $\begin{array}{l}\text { more than } \\
100\end{array}$ & $\begin{array}{c}\text { more than } \\
100\end{array}$ & $\begin{array}{c}\text { more than } \\
100\end{array}$ & $\begin{array}{c}\text { more than } \\
100\end{array}$ & $\begin{array}{c}\text { more than } \\
100\end{array}$ & 0_30 & $\begin{array}{c}\text { more than } \\
100\end{array}$ \\
\hline Population & 90_120 & 0-30 & 90_120 & $\begin{array}{l}\text { More than } \\
120\end{array}$ & 60_90 & $30 \_60$ & 0_30 & 0_30 \\
\hline Subway & $\begin{array}{l}\text { More than } \\
\quad 300\end{array}$ & $\begin{array}{l}\text { More than } \\
\quad 300\end{array}$ & $\begin{array}{l}\text { More than } \\
300\end{array}$ & $\begin{array}{l}\text { More than } \\
\quad 300\end{array}$ & $\begin{array}{l}\text { More than } \\
300\end{array}$ & $\begin{array}{l}\text { More than } \\
300\end{array}$ & $0 \_50$ & $\begin{array}{c}\text { More than } \\
300\end{array}$ \\
\hline Fault & $\begin{array}{l}\text { More than } \\
\quad 400\end{array}$ & $\begin{array}{l}\text { More than } \\
\quad 400\end{array}$ & $\begin{array}{l}\text { More than } \\
400\end{array}$ & $\begin{array}{l}\text { More than } \\
\quad 400\end{array}$ & $400-200$ & $400-200$ & 0_100 & $\begin{array}{c}\text { More than } \\
\quad 400\end{array}$ \\
\hline Health centers & 0_200 & $0-200$ & $700-1000$ & $200 \_500$ & $200 \_500$ & 700_1000 & 200_500 & 200_500 \\
\hline Rivers & $\begin{array}{l}\text { More than } \\
\quad 700\end{array}$ & $\begin{array}{l}\text { More than } \\
\quad 700\end{array}$ & $500-700$ & $200 \_500$ & 0_100 & $\begin{array}{l}\text { More than } \\
700\end{array}$ & 0_100 & $\begin{array}{c}\text { More than } \\
700\end{array}$ \\
\hline $\begin{array}{l}\text { Educational } \\
\text { centers }\end{array}$ & 150_300 & 0_150 & 0_150 & 150_300 & 150_300 & 300_500 & 150_300 & 150_300 \\
\hline $\begin{array}{l}\text { Parks and } \\
\text { gardens }\end{array}$ & $200-400$ & 0_200 & 0_200 & 0_200 & 0_200 & 0_200 & 0_200 & 200_400 \\
\hline
\end{tabular}

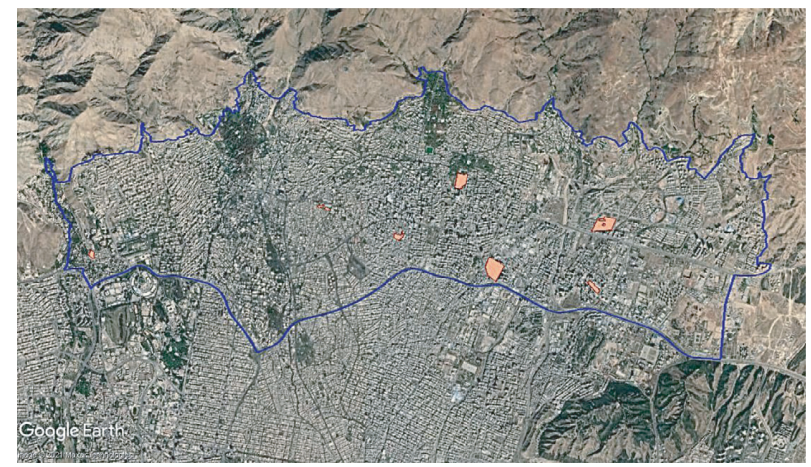

Figure 11: Optimal areas extracted by GIS in the zone.

efficiency of operational units (or DMUs-decision-making units-in the DEA), it is common to compare input criteria (different resources allocated to the units) to output criteria (results generated by the activity of the units) and to look for some kind of "best" output/input ratio [29, 30]. Suppose we have $n$ DMUs, where $\operatorname{DMUj}(j=1, \ldots, n)$ uses $m$ inputs $x_{i j}$ 


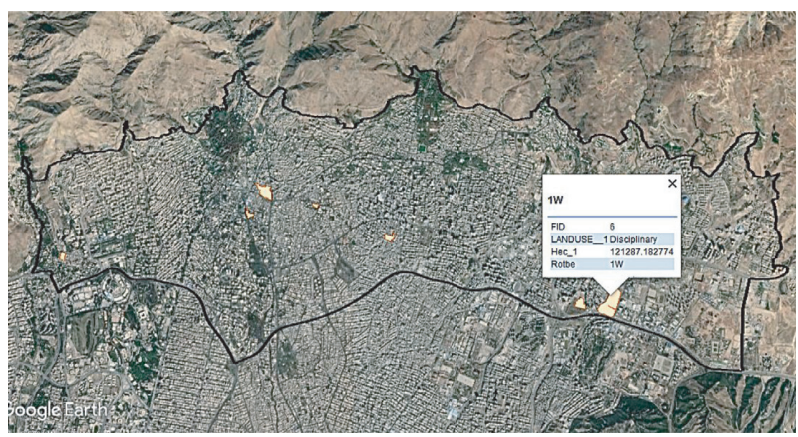

Figure 12: Military area (one of the optimal output areas of GIS).

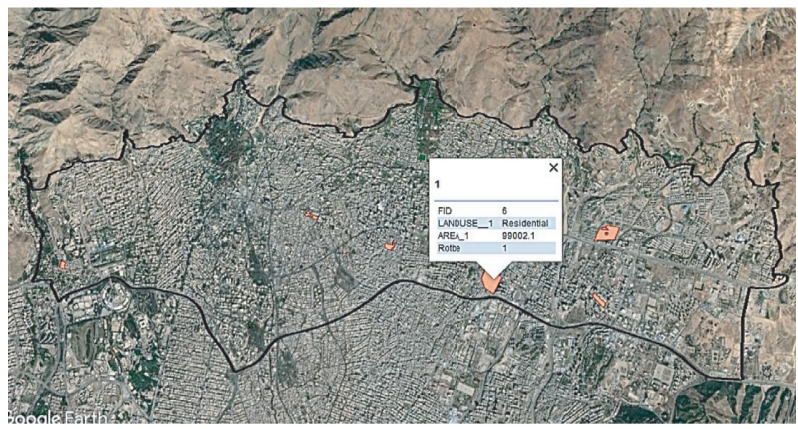

Figure 13: Residential area (one of the optimal output areas of GIS).

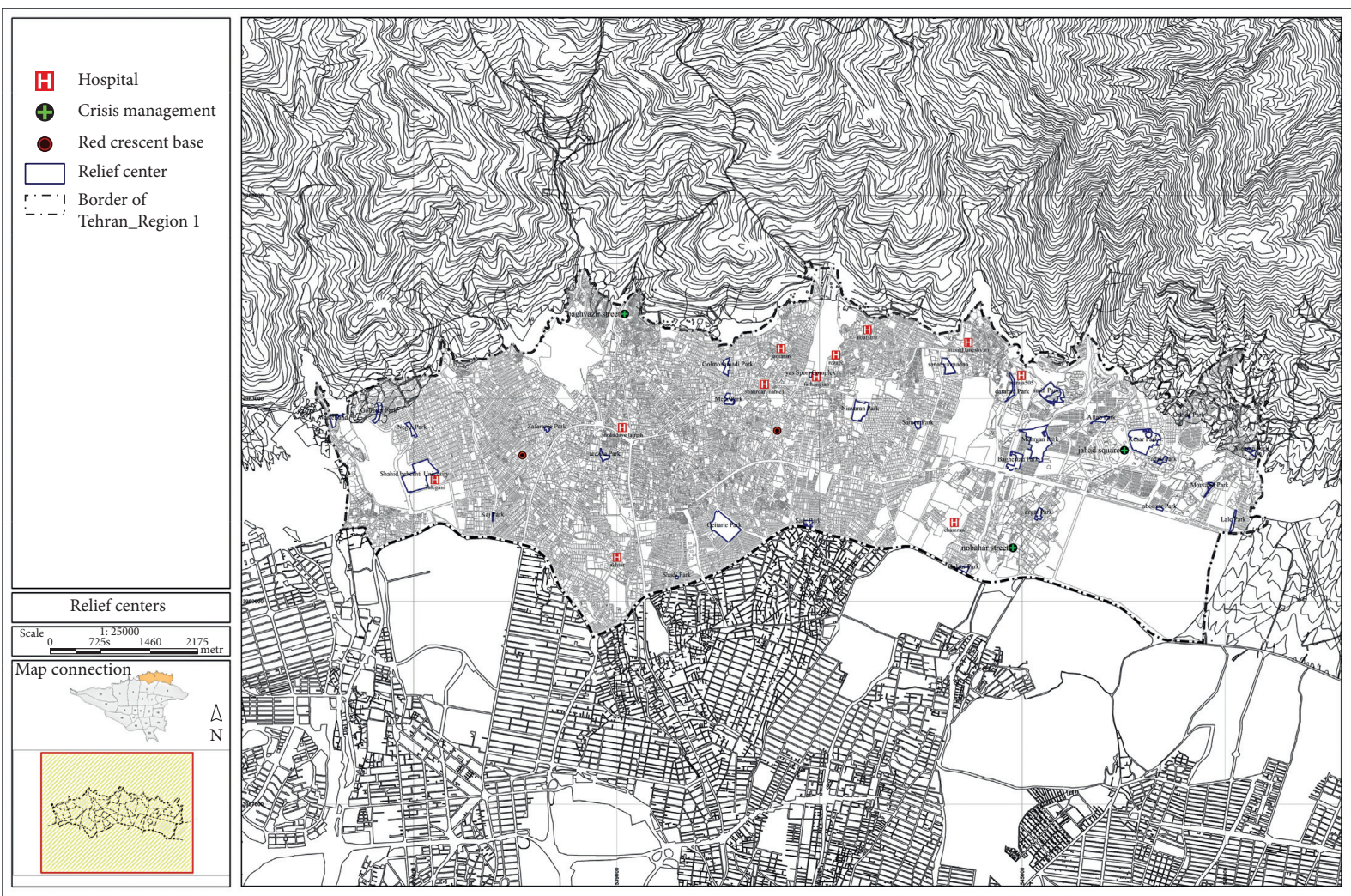

Figure 14: Relief centers for crisis accommodation in area 1. 


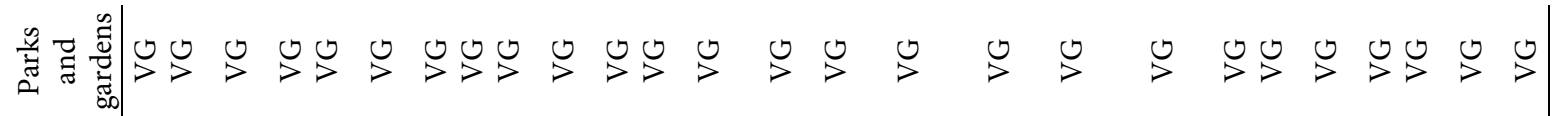

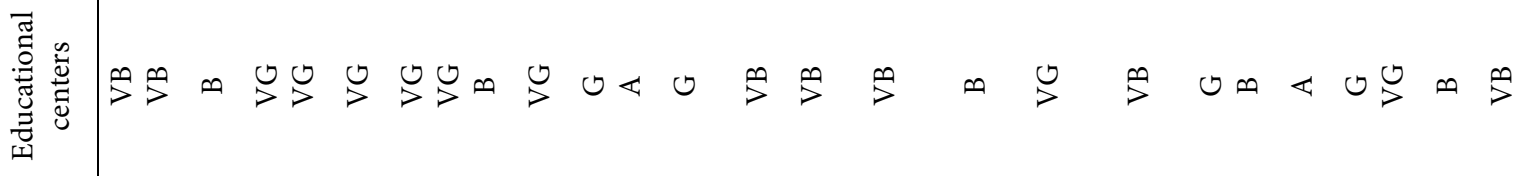
兽

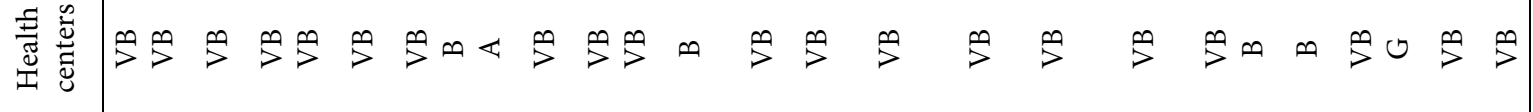
壹

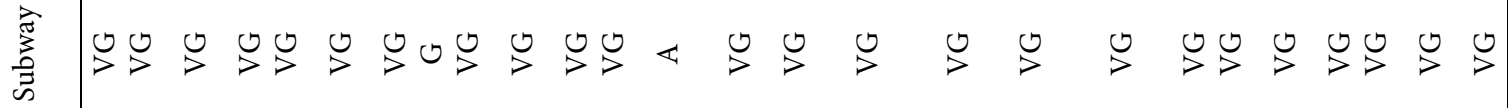
总

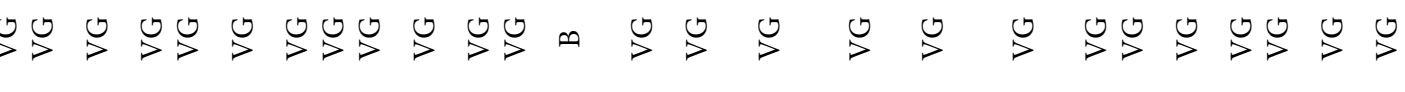

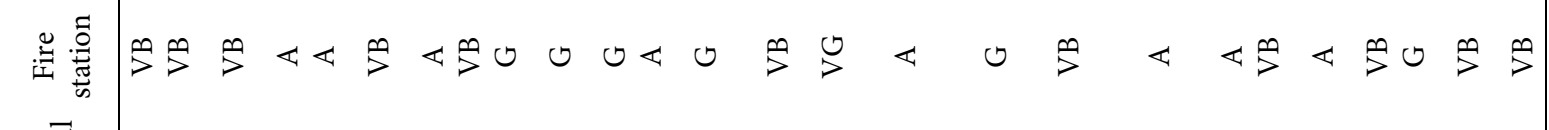

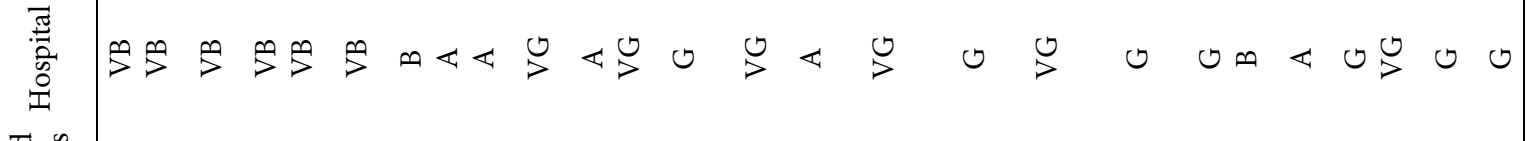

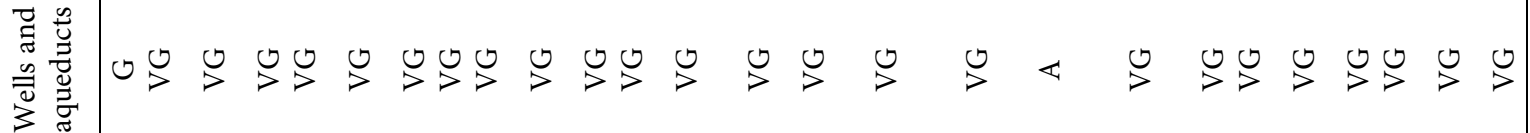

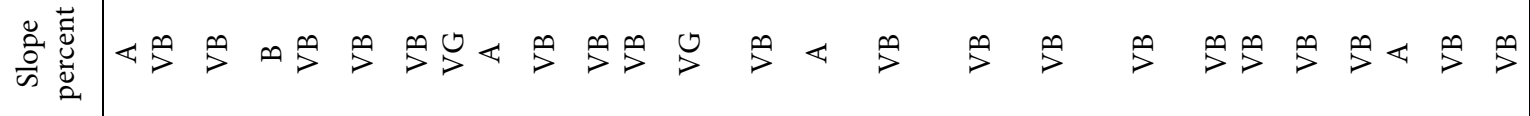
岂莺

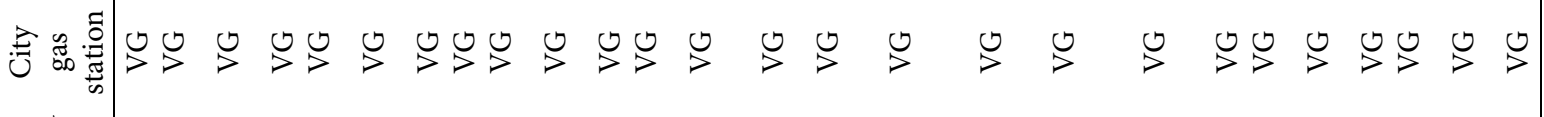
害

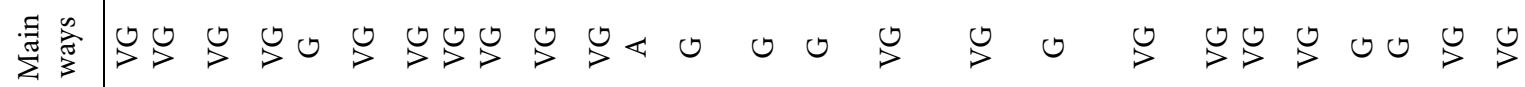
蒫瓦

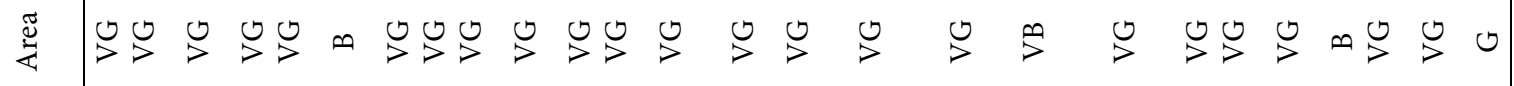

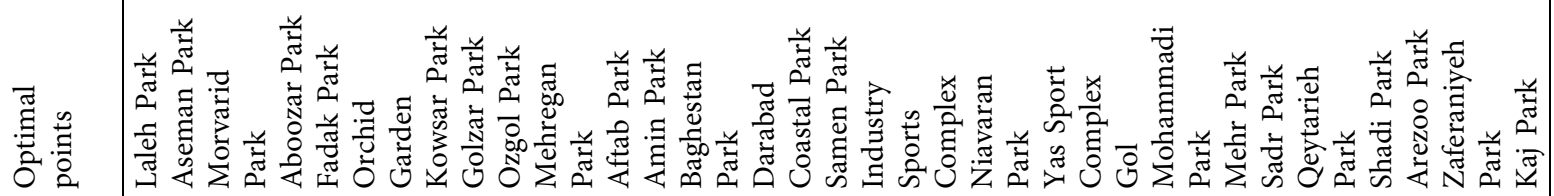




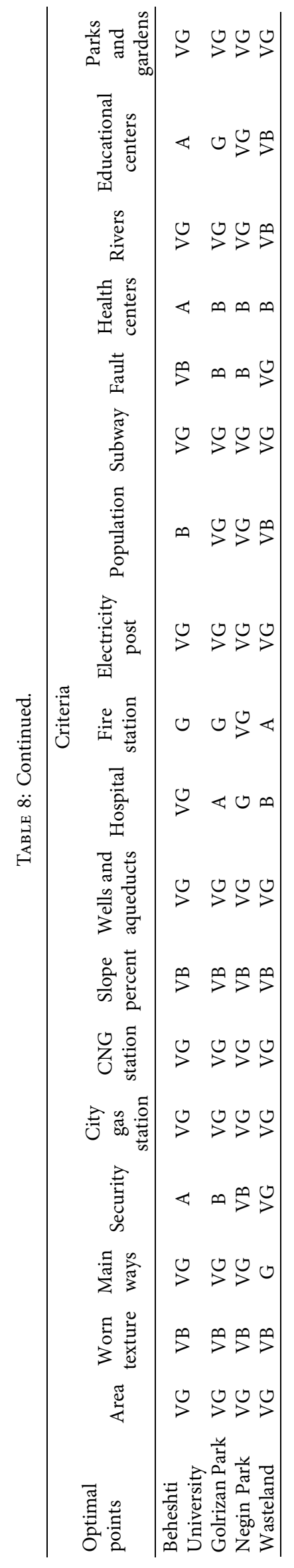


TABLE 9: Weight of criteria calculated by the entropy method.

\begin{tabular}{lr}
\hline Criteria & $W_{j}$ \\
\hline Area & 0.0559 \\
Worn texture & 0.047 \\
Main ways & 0.0576 \\
Security & 0.0556 \\
City gas station & 0.0575 \\
CNG station & 0.0575 \\
Percent slope & 0.0514 \\
Wells and aqueducts & 0.0573 \\
Hospital & 0.0561 \\
Fire station & 0.0542 \\
Electricity post & 0.0573 \\
Population & 0.0556 \\
Subway & 0.0573 \\
Fault & 0.0562 \\
Health centers & 0.0515 \\
Rivers & 0.0589 \\
Educational centers & 0.0556 \\
Parks and gardens & 0.0575 \\
\hline
\end{tabular}

TABLE 10: MOORA method ranking results.

\begin{tabular}{|c|c|c|}
\hline Rank & Options & $Y_{i}$ \\
\hline 1 & Morvarid Park & 0.10128 \\
\hline 2 & Gol Mohammadi Park & 0.10109 \\
\hline 3 & Negin Park & 0.09347 \\
\hline 4 & Maher Park & 0.09332 \\
\hline 5 & Kaj Park & 0.0909 \\
\hline 6 & Orchid Garden & 0.0891 \\
\hline 7 & Aboozar Park & 0.0864 \\
\hline 8 & Sadr Park & 0.08616 \\
\hline 9 & Kowsar Park & 0.08504 \\
\hline 10 & Fadak Park & 0.08453 \\
\hline 11 & Industry Sports Complex & 0.0834 \\
\hline 12 & Golzar Park & 0.08311 \\
\hline 13 & Aftab Park & 0.08255 \\
\hline 14 & Zaferaniyeh Park & 0.08222 \\
\hline 15 & Amin Park & 0.08204 \\
\hline 16 & Shadi Park & 0.08204 \\
\hline 17 & Ozgol Park & 0.08167 \\
\hline 18 & Yas Sport Complex & 0.08153 \\
\hline 19 & Arezoo Park & 0.08134 \\
\hline 20 & Wasteland & 0.07764 \\
\hline 21 & Samen Park & 0.07725 \\
\hline 22 & Mehregan Park & 0.07646 \\
\hline 23 & Darabad Coastal Park & 0.07604 \\
\hline 24 & Aseman Park & 0.06842 \\
\hline 25 & Baghestan Park & 0.06321 \\
\hline 26 & Niavaran Park & 0.06189 \\
\hline 27 & Shahid Beheshti University & 0.06068 \\
\hline 28 & Golrizan Park & 0.05907 \\
\hline 29 & Laleh Park & 0.05538 \\
\hline 30 & Qeytarieh Park & 0.03015 \\
\hline
\end{tabular}


TABle 11: The values of the flows calculated by the PROMETHEE method.

\begin{tabular}{lccc}
\hline Actions & $\varnothing$ & $\varnothing^{+}$ & $\varnothing$ \\
\hline P5 & 0.1232 & 0.2947 & 0.1715 \\
P6 & 0.1208 & 0.3068 & 0.1860 \\
PW8 & 0.1159 & 0.2633 & 0.1473 \\
P4 & 0.0942 & 0.2633 & 0.1691 \\
PW1 & 0.0870 & 0.2633 & 0.1763 \\
P3 & 0.0821 & 0.2705 & 0.1884 \\
PW6 & 0.0580 & 0.2947 & 0.2367 \\
PW2 & 0.0531 & 0.2826 & 0.2295 \\
P1 & 0.0386 & 0.2633 & 0.2246 \\
PW4 & 0.0362 & 0.2609 & 0.2246 \\
Niavaran Park & 0.0362 & 0.2246 & 0.1884 \\
PW3 & 0.0169 & 0.2657 & 0.2488 \\
P2 & 0.0048 & 0.2609 & 0.2560 \\
P7 & -0.0048 & 0.2778 & 0.2826 \\
PW5 & -0.0072 & 0.2657 & 0.2729 \\
P8 & -0.0072 & 0.2029 & 0.2101 \\
Mohammadi Park & -0.0145 & 0.1884 & 0.2029 \\
PW7 & -0.0290 & 0.2995 & 0.3285 \\
Amin Park & -0.0894 & 0.1836 & 0.2729 \\
Darabad Park & -0.0918 & 0.1860 & 0.2778 \\
Qeytarieh Park & -0.1087 & 0.1812 & 0.1425 \\
Aseman Park & -0.1570 & 0.1498 & 0.1256 \\
Shadi Park & -0.1715 & -0.1860 & 0.2995 \\
Morvarid Park & & 0.3213 \\
\hline
\end{tabular}

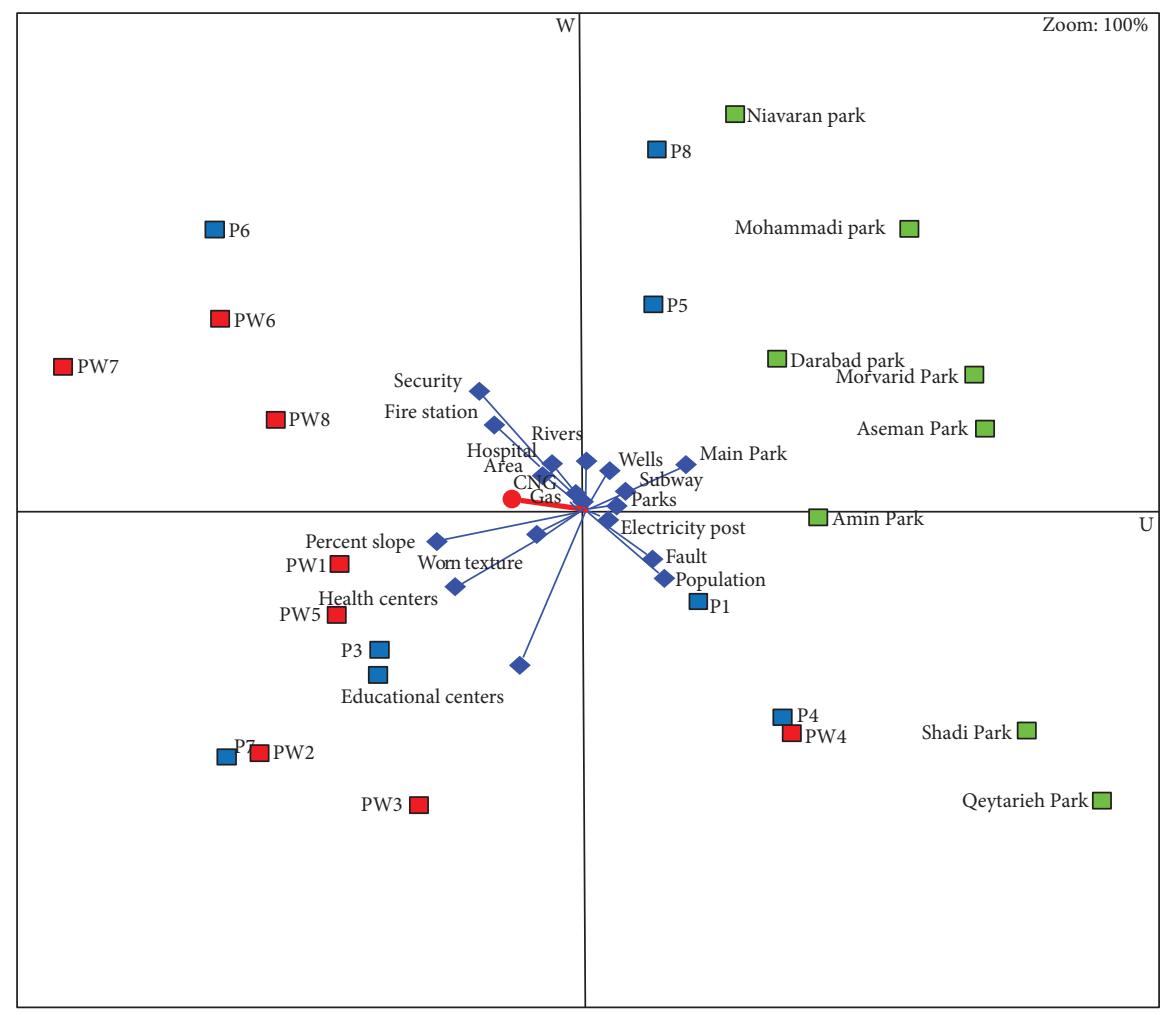

FIGURE 15: GAYA PROMETHEE diagram for analyzing criteria and options. 
TABLE 12: Limitations and optimal options offered by PROMETHEE V.

\begin{tabular}{|c|c|c|c|c|c|c|}
\hline Actions & & $\begin{array}{l}\text { Net flow } \\
\text { TOTAL }\end{array}$ & \multicolumn{2}{|c|}{ Optimal } & Compare & \\
\hline P1 & & 0.0386 & \multicolumn{2}{|c|}{ Yes } & \multicolumn{2}{|c|}{ Yes } \\
\hline $\mathrm{P} 2$ & & 0.0048 & \multicolumn{2}{|c|}{ Yes } & \multicolumn{2}{|c|}{ Yes } \\
\hline P3 & & 0.0821 & \multicolumn{2}{|c|}{ Yes } & \multicolumn{2}{|c|}{ Yes } \\
\hline $\mathrm{P} 4$ & & 0.0942 & \multicolumn{2}{|c|}{ Yes } & \multicolumn{2}{|c|}{ Yes } \\
\hline P5 & & 0.1232 & \multicolumn{2}{|c|}{ Yes } & \multicolumn{2}{|c|}{ Yes } \\
\hline P6 & & 0.1208 & \multicolumn{2}{|c|}{ Yes } & \multicolumn{2}{|c|}{ Yes } \\
\hline P7 & & -0.0048 & \multicolumn{2}{|c|}{ No } & \multicolumn{2}{|c|}{ No } \\
\hline P8 & & -0.0072 & \multicolumn{2}{|c|}{ No } & \multicolumn{2}{|c|}{ No } \\
\hline PW1 & & 0.0870 & \multicolumn{2}{|c|}{ Yes } & \multicolumn{2}{|c|}{ Yes } \\
\hline PW2 & & 0.0531 & \multicolumn{2}{|c|}{ Yes } & \multicolumn{2}{|c|}{ Yes } \\
\hline PW3 & & 0.0169 & \multicolumn{2}{|c|}{ Yes } & \multicolumn{2}{|c|}{ Yes } \\
\hline PW4 & & 0.0362 & \multicolumn{2}{|c|}{ Yes } & & \\
\hline PW5 & & -0.0072 & & & & \\
\hline PW6 & & 0.0580 & & & & \\
\hline PW7 & & -0.0290 & & & & \\
\hline PW8 & & 0.1159 & & & & \\
\hline Aseman Park & & -0.1570 & & & & \\
\hline Morvarid Park & & -0.1860 & & & & \\
\hline Mohammadi Park & & -0.0145 & & & & \\
\hline Darabad Park & & -0.0918 & & & & \\
\hline Amin Park & & -0.0894 & & & & \\
\hline Qeytarieh Park & & -0.1087 & & & & \\
\hline Shadi Park & & -0.1715 & & & & \\
\hline Niavaran Park & & 0.0362 & & & & \\
\hline Constraints & & Optimal & & & $\mathrm{mp}$ & \\
\hline & LHS & & RHS & LHS & & RHS \\
\hline Minimum & 13.00 & $\geq$ & 1 & 13.00 & $\geq$ & 1 \\
\hline Maximum & 13.00 & $\leq$ & 24 & 13.00 & $\leq$ & 24 \\
\hline Gas & 18205 & $\geq$ & 400 & 18205 & $\geq$ & 400 \\
\hline $\mathrm{CNG}$ & 147900 & $\geq$ & 400 & 147900 & $\geq$ & 400 \\
\hline Wells & 10190 & $\geq$ & 50 & 10190 & $\geq$ & 50 \\
\hline Electricity post & 22281 & $\geq$ & 30 & 22281 & $\geq$ & 30 \\
\hline Subway & 16345 & $\geq$ & 50 & 16345 & $\geq$ & 50 \\
\hline Fault & 9110 & $\geq$ & 100 & 9110 & $\geq$ & 100 \\
\hline Rivers & 12680 & $\geq$ & 100 & 12680 & $\geq$ & 100 \\
\hline
\end{tabular}

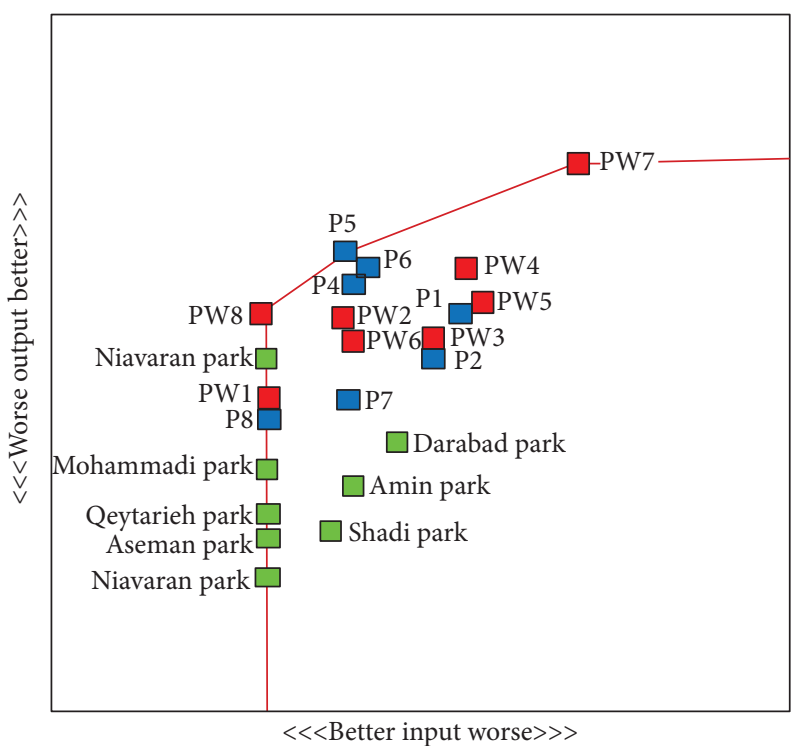

Figure 16: Performance of efficient options and inefficient options of research. 


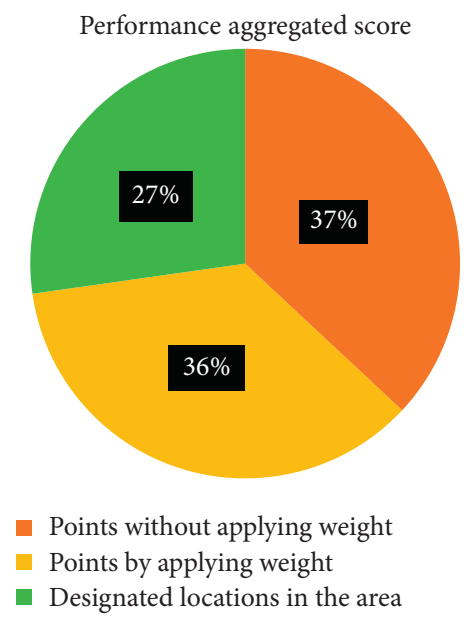

Figure 17: Comparing the overall performance of the options.

$(i=1, \ldots, m)$ to produce $s$ outputs $y_{r j}(r=1, \ldots, s)$. DEA uses the following model for evaluating kth DMU's efficiency (denoted by $\theta$ ):

$$
\begin{aligned}
& \min \theta \\
& \text { s.t: } \sum_{j} \lambda_{j} x_{i j} \leq \theta x_{i o}, \quad \forall i \sum_{j} \lambda_{j} y_{r j} \geq y_{r o}, \quad \forall r \lambda_{j}, \quad \theta \geq 0 \forall i, j, r .
\end{aligned}
$$

\section{Conclusion}

In this study, the proposed locations of the Regional Crisis Management Organization and the proposed optimal points of the GIS according to 18 standardized criteria were evaluated. Also, by examining the feasibility of the optimal areas extracted by the GIS, the applicability or nonapplicability of the optimal areas introduced in crises has been addressed. The information layers were overlapped once by applying the criteria weight and once without applying the weight, and the optimal points were extracted. Each point (weighted and without weight) was evaluated and scored by GIS according to the indicators. In the next step, the designated crisis management locations in the study area are evaluated concerning the problem indicators and ranked by the MOORA method. By entering the qualitative information of the optimal location and points in the PROMETHEE method, each of the suggested points was evaluated. Finally, considering the amount of net flow $(\varphi)$ and the performance score of each of the options and by applying constraints, the optimal and efficient options were determined. Limitations include the minimum and maximum options for selecting relief sites ranging from 1 to 24 options and restrictions that must meet the standard distance set by crisis management experts. The results showed good performance of areas without weight application (37\%) and optimal areas with weight application (36\%) compared with the proposed locations of the Regional Crisis Management Organization (27\%) so that the results of the net flow performance analysis and the score of each of the options (see Figure 3) indicate the superiority of points without applying weights.

The reason for the closeness of the results of the GIS can be considered the reasonable opinion of experts. The noteworthy point of this research is the performance of the considered places in the region, which have not been very satisfactory. The difference in the performance of $10 \%$ of GIS output with the locations in the region can be considered the poor performance of these locations in some indicators. The performance of the places means the top eight places in the region (the top eight places in the MOORA ranking), but if we examine other places concerning these optimal places and standard criteria, we will see more worrying results. Also, by applying research limitations, it was found that only 13 out of 24 research options were optimal. According to the net input and output flows, the 14 options do not have the necessary performance for crises [31, 32].

Due to the high importance of location, especially the location of relief centers, and due to the high sensitivity of these centers, the use of more accurate and reliable methods should be a priority. It is recommended that managers and staff of the Regional Crisis Management Organization consider these places in terms of cost and economic criteria.

\section{Data Availability}

The data are available upon request. 


\section{Conflicts of Interest}

The authors declare that they have no conflicts of interest.

\section{References}

[1] F. Sabouhi, Z. S. Tavakoli, A. Bozorgi-Amiri, and J. B. Sheu, "A robust possibilistic programming multi-objective model for locating transfer points and shelters in disaster relief," Transportmetrica A: Transport Science, vol. 15, no. 2, pp. 326-353, 2019.

[2] D. Guha-Sapir, F. Vos, R. Below, and S. Ponserre, Annual Disaster Statistical Review 2011: The Numbers and Trends, Centre for Research on the Epidemiology of Disasters (CRED), Brussels, Belgium, 2012.

[3] J. A. Vega and C. A. Hidalgo, "Quantitative risk assessment of landslides triggered by earthquakes and rainfall based on direct costs of urban buildings," Geomorphology, vol. 273, pp. 217-235, 2016.

[4] M. GhafouriAshtiani, Seismic Risk Reduction in Tehran, National Committee to Reduce the Effects of Natural Disasters, Tehran, Iran, in Persian, 2001.

[5] S. Yasuda and T. Hashimoto, "New project to prevent liquefaction-induced damage in a wide existing residential area by lowering the ground water table," Soil Dynamics and Earthquake Engineering, vol. 91, pp. 246-259, 2016.

[6] S. A. Hosseini and H. H. Machyani, "Locating sites for temporary accommodation and food storage silos in the event of a crisis in rasht city-Iran," J. Mater. Environ. Sci, vol. 6, no. 10, pp. 2825-2835, 2015.

[7] M. Esmaelian, M. Tavana, F. J. S. Arteaga, and S. Mohammadi, "A multicriteria spatial decision support system for solving emergency service station location problems," International JournalOf Geographical Information Science, vol. 29, no. 7, pp. 1187-1213, 2015.

[8] J. M. Marcelin, M. W. Horner, and E. E. Ozguven, "How does accessibility to post disaster relief compare between the aging and the generalpopulation? A spatial network optimization analysis of hurricane relief facility locations," International Journal of Disaster Risk Reduction, vol. 15, pp. 61-72, 2016.

[9] W. Chen, G. Zhai, C. Fan, W. Jin, and Y. Xie, "A planning framework based on system theory and GIS for urban emergency shelter system: a case of Guangzhou, China," Human and Ecological Risk Assessment: An International Journal, vol. 23, no. 3, pp. 441-456, 2017.

[10] B. Saeidian, M. S. Mesgari, B. Pradhan, and M. Ghodousi, "Optimized location-allocation of earthquake relief centers using PSO and ACO, complemented by GIS, clustering, and TOPSIS," ISPRS International Journal of Geo-Information, vol. 7, no. 8, p. 292, 2018.

[11] M. M. L. Nappi, V. Nappi, and J. C. Souza, "Multi-criteria decision model for the selection and location of temporary shelters in disaster management," Journal of International Humanitarian Action, vol. 4, no. 1, p. 16, 2019.

[12] H. Baharmand, T. Comes, and M. Lauras, "Supporting group decision makers to locate temporary relief distribution centres after sudden-onset disasters: a case study of the 2015 Nepal earthquake," International Journal of Disaster Risk Reduction, vol. 45, Article ID 101455, 2020.

[13] K. Borhani, A. AzimzadehIrany, and A. Elhami, "Spatial analysis of urban multi-functional land uses integrating MCDM and GIS methods Case study: emergency shelter in
Saravan City," Scientific-Research Quarterly of Geographical Data (SEPEHR), vol. 29, no. 116, pp. 103-118, 2021.

[14] H. Su, W. Chen, and M. Cheng, "Using the variable two-step floating catchment area method to measure the potential spatial accessibility of urban emergency shelters," GeoJournal, pp. 1-15, 2021.

[15] Y. Yao, Y. Zhang, T. Yao, K. Wong, J. Y. Tsou, and Y. Zhang, "A GIS-based system for spatial-temporal availability evaluation of the open spaces used as emergency shelters: the case of Victoria, British Columbia, Canada," ISPRS International Journal of Geo-Information, vol. 10, no. 2, p. 63, 2021.

[16] R. M. Gray, Entropy and Information Theory, Springer Science \& Business Media, Berlin, Germany, 2011.

[17] W. K. Brauers and E. K. Zavadskas, "The MOORA method and its application to privatization in a transition economy," Control and Cybernetics, vol. 35, pp. 445-469, 2006.

[18] A. Azar and A. Rajabzadeh, "Applied decision making of MADM approach, tehran,” 2010.

[19] P. Ghasemi and E. TalebiBrijani, "An integrated FAHPPROMETHEE approach for selecting the best Flexible manufacturing system," European Online Journal of Natural and Social Sciences, vol. 3, no. 4, p. 1137, 2014

[20] S. Mamalis, I. Kamenidou, S. Pavlidis, and A. Xatziaggelou, "Perceptions of hospital quality: a case study from Greece," in Strategic Innovative Marketing and Tourism, pp. 403-410, Springer, Cham, Switzerland, 2020.

[21] M. Behzadian, R. B. Kazemzadeh, A. Albadvi, and M. Aghdasi, "PROMETHEE: a comprehensive literature review on methodologies and applications," European Journal of Operational Research, vol. 200, no. 1, pp. 198-215, 2010.

[22] S. Greco, J. Figueira, and M. Ehrgott, Multiple Criteria Decision Analysis, Springer, New York, NY, USA, 2016.

[23] X. Qi, X. Yu, L. Wang, X. Liao, and S. Zhang, "PROMETHEE for prioritized criteria," in Soft Computingvol. 23, no. 22, pp. 11419-11432, 2019.

[24] P. Verma, "Promethee: a tool for multi-criteria decision analysis," in Multi-Criteria Decision Analysis in Management, pp. 282-309, IGI Global, Hershey, PA, USA, 2020.

[25] Habibi, M. Seyed, and M. Sedigheh, Per Capita Urban Land Use, National Land and Housing Organization Publications, Tehran, Iran, 1999.

[26] L. Zhao, H. Li, Y. Sun et al., "Planning emergency shelters forUrban disaster resilience: an integrated location-allocation modeling approach," Sustainability, vol. 9, no. 11, p. 2098, 2017.

[27] C. Jica, "The study on seismic microzoning of the Greater Tehran Area in the Islamic Republic of Iran," Pacific Consultants International Report, OYO Cooperation, Tokyo, Japan, 2000.

[28] A. Baležentis, T. Baležentis, and W. Brauers, "MULTIMOORA-FG: a multi-objective decision making method for linguistic reasoning with an application to personnel selection," Informatica, vol. 23, no. 2, pp. 173-190, 2012.

[29] T. Balezentis and A. Balezentis, "A survey on development and applications of the multicriteria decision making MethodMULTIMOORA," Journal of Multi-Criteria Decision Analysis, vol. 21, pp. 209-222, 2014.

[30] F. Jolai, M. J. Rezaee, and A. Vazifeh, "Multi-criteria decision making for assembly line balancing," Journal of Intelligent Manufacturing, vol. 20, no. 1, pp. 113-121, 2009.

[31] M. J. Rezaee and S. Yousefi, "An intelligent decision making approach for identifying and analyzing airport risks," Journal of Air Transport Management, vol. 68, pp. 14-27, 2018. 